Marcello Schiavo Nardi

Pesquisa de Leishmania sp. em flebótomos e mamíferos silvestres de fragmentos florestais na região do Pontal do Paranapanema, SP

São Paulo 
Marcello Schiavo Nardi

\section{Pesquisa de Leishmania sp. em flebótomos e mamíferos silvestres de fragmentos florestais na região do Pontal do \\ Paranapanema, SP}

Dissertação apresentada ao Programa de Pós-Graduação em Epidemiologia Experimental Aplicada às Zoonoses da Faculdade de Medicina Veterinária e Zootecnia da Universidade de São Paulo para obtenção do título de Mestre em Ciências

\section{Departamento:}

Medicina Veterinária Preventiva e Saúde Animal

Área de Concentração:

Epidemiologia Experimental Aplicada às Zoonoses

Orientador:

Prof. Dr. Fernando Ferreira

São Paulo 
Autorizo a reprodução parcial ou total desta obra, para fins acadêmicos, desde que citada a fonte.

DADOS INTERNACIONAIS DE CATALOGAÇÃO-NA-PUBLICAÇÃO

(Biblioteca Virginie Buff D’Ápice da Faculdade de Medicina Veterinária e Zootecnia da Universidade de São Paulo)

FMVZ Pesquisa de Leishmania sp. em flebótomos e mamíferos silvestres de fragmentos florestais na região do Pontal do Paranapanema, SP / Marcello Schiavo Nardi. -- 2010.

63 f. : il.

Dissertação (Mestrado) - Universidade de São Paulo. Faculdade de Medicina Veterinária e Zootecnia. Departamento de Medicina Veterinária Preventiva e Saúde Animal, São Paulo, 2010.

Programa de Pós-Graduação: Epidemiologia Experimental Aplicada às Zoonoses.

Área de concentração: Epidemiologia Experimental Aplicada às Zoonoses.

Orientador: Prof. Dr. Fernando Ferreira.

1. Pontal do Paranapanema. 2. Flebotomíneos. 3. Mamíferos Silvestres. 4. Leishmania. 5. Fragmentação florestal. I. Título. 


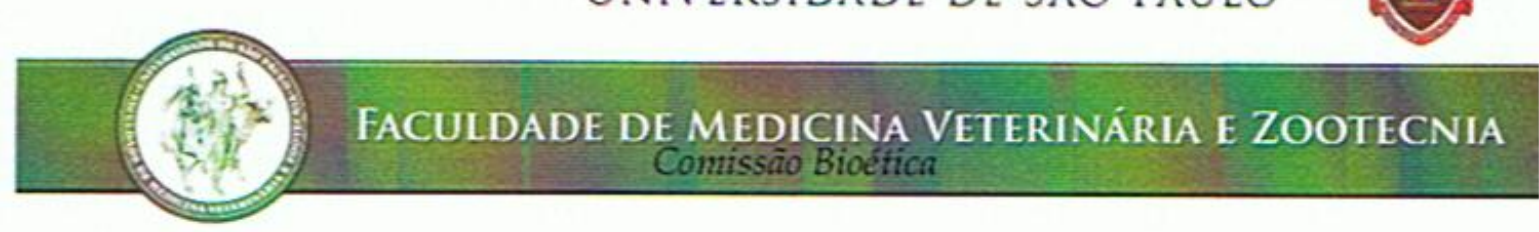

\section{CERTIFICADO}

Certificamos que o Projeto intitulado "Avaliação dos efeitos da fragmentação florestal na ecologia de flebótomos e reservatórios selvagens para Leishmania sp. na região do Pontal do Paranapanema-SP", protocolado sob o n $1411 / 2008$, utilizando número de animais de acordo com o resultado das capturas (roedores, marsupiais e flebotomíneos), sob a responsabilidade do Prof. Dr. Fernando Ferreira, está de acordo com os princípios éticos de experimentação animal da Comissão de Bioética da Faculdade de Medicina Veterinária e Zootecnia da Universidade de São Paulo e foi aprovado "ad referendum".

(We certify that the Research "Assessment of forest fragmentation effects in the ecology of sand-files and wild reservoirs for Leishmania sp. in the Pontal of Paranapanema Region, SP", protocol number 1411/2008, under the responsibility Prof. Dr. Fernando Ferreira k, agree with Ethical Principles in Animal Research adopted by Bioethic Commission of the School of Veterinary Medicine and Zootechny of University of São Paulo and was approved "ad referendum" meeting).

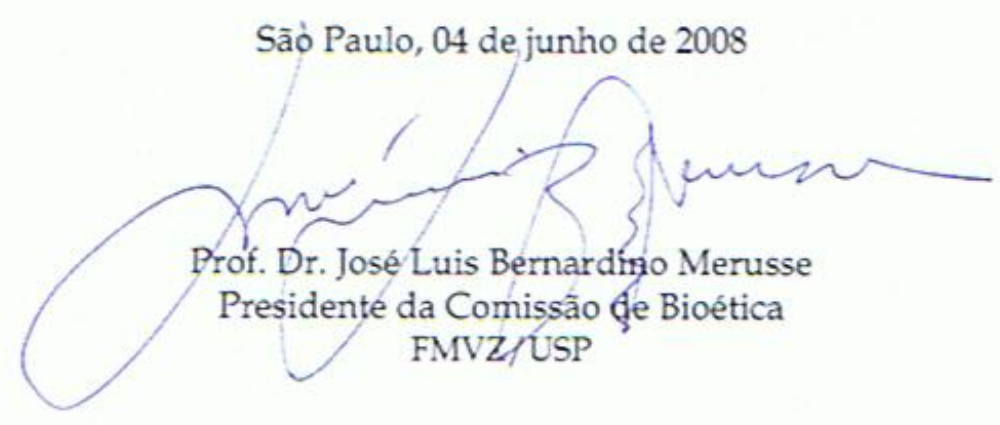




\section{FOLHA DE AVALIAÇÃO}

Nome: NARDI, Marcello Schiavo

Título: Pesquisa de Leishmania sp. em flebótomos e mamíferos silvestres de fragmentos florestais na região do Pontal do Paranapanema, SP.

Dissertação apresentada ao Programa de PósGraduação em Epidemiologia Experimental Aplicada às Zoonoses da Faculdade de Medicina Veterinária e Zootecnia da Universidade de São Paulo para obtenção do título de Mestre em Ciências

Data:

Banca Examinadora

Prof. Dr. Instituição:

Assinatura: Julgamento:

Prof. Dr. Instituição:

Assinatura: Julgamento:

Prof. Dr. Instituição:

Assinatura: Julgamento: 
Dedico este trabalho à fauna do Pontal do Paranapanema e aos meus pais Plinio e Maiby, minhas irmãs carla e Tatiana e minha tía cecilía Pelo apoio e compreensão em todos os momentos desta caminhada, 


\section{AGRADECIMENTOS}

Este trabalho foi bastante abrangente e envolveu muitas pessoas, portanto, lembrar de todos torna-se uma tarefa difícil, ainda quando escrevemos os agradecimentos nos últimos minutos antes do depósito da dissertação.

Novamente, agradeço aos meus pais, Plínio e Maiby, minhas irmãs Carla e Tatiana e minha tia Cecília pelo amor, apoio e compreensão, e por terem me proporcionado a educação necessária para evoluir na vida pessoal e profissional.

Em especial, ao meu orientador Fernando Ferreira, pela amizade, a solução dos problemas levantados, o apoio nas dúvidas e por ter ajudado na obtenção do recurso financeiro junto à FAPESP

Em especial, à Prof. Eunice Aparecida Bianchi Galati pela amizade e o conhecimento transmitido. É uma pessoa diferenciada e que sem dúvida foi imprescindível para realização deste trabalho.

Em especial, ao professor Rodrigo Martins Soares, pela imensa ajuda nas análises moleculares das amostras e por me ajudar nos momentos de dúvidas.

Em especial, à Roberta Marcatti, por me ajudar nas coletas, no processamento das amostras e por me suportar em todos os momentos.

Em especial, à Estela Gallucci e ao João, pela imensa força no processamento das amostras e por responder quase que prontamente as minhas solicitações e dúvidas

Em especial à Elza Faquim, da biblioteca, pelo auxílio e rapidez nas correções desta dissertação e Tânia Delonero, pelos esclarecimentos das minhas dúvidas.

À Alessandra Nava pelas oportunidades proporcionadas, a amizade e as dicas profissionais

À Cristina Tófoli, pela amizade, por me ensinar a cozinhar e morar sozinho, aos dias de campo intensos, as bebedeiras, enfim, por ser a minha irmã no Pontal

Á Maíra Posteraro, pela amizade, por estar junto nos momentos de perrengue das coletas e pela força no laboratório (Ahhh Itália!!).

Á Marina Seixas, pela amizade, a ajuda nas atividades de campo e laboratoriais e a hospedagem maravilhosa na Cidade Maravilhosa.

Á estagiária Camila Luba, e aos estagiários Caio e Erick, pela ajuda

A todo o pessoal do Pontal, em especial ao Bruno Lima, Nivaldo, Waltinho (Chega chooora!!), Daniel Gordo, Manu, Fer e Leandra, pela amizade, pela força no campo, as risadas, as Brahmas, os sons, os rangos e os roles. Saudades galera!!!! 
Ao IPÊ e toda sua equipe pelo apoio logístico, em especial, ao Alexandre Uezu, que me ajudou no desenho amostral deste projeto, Laury Cullen Jr., Fernando Lima, Aires, Karla Paranhos, Gracinha, Miriam, Tiago, Thais, Vicente, Haroldo e Cássio.

Ao Seu Cícero, com quem aprendi muito, exemplo de perseverança e humildade, por me ajudar na abertura das trilhas, nas coletas e pelo carneiro na despedida.

Aos assistentes de campo Cicinho, Zezinho, Wilson, Tica e Junior pela ajuda.

Aos colegas do LEB, Monica Solorio, Grisi, Risia, Mauro, Aline, Ana Julia, Vanessinha, Bianca Matunga, Bianca, Carol, Guilherme, pela amizade e ajuda.

A todos os colegas do VPS, em especial à Fernanda Nieri, Thiaguinho, Guima, Waltinho, Jonas, Gaúcho, Danival, Maria, Adriano Pinter, Mauricio, Sibele, Vanessa, Sheila, Fininho, Pedrinho, Serginho, Bruno mineiro, Patrick, Aliny, Guacyara, Juliana e as Camilas.

Aos professores Ricardo, Zezé, Nilson, Solange, Silvio e em especial ao Marcelo Labruna, por ceder o espaço do laboratório e permitir a utilização de alguns materiais de consumo

Ao pessoal da Saúde Pública, Freddy, Zé Carlos, Edna e Aristides

Ao pessoal do Parque Estadual Morro do Diabo, Andrea Pires, Alex, Homero, Eurico e Raul

À Ricardo Bovendorf pela identificação dos roedores.

Ao IBAMA, pela concessão da licença

À FAPESP (processo 07/52160-0) pelo apoio financeiro.

Ás colegas da prefeitura de São Paulo Fátima, Joana, Samantha e a Dra. Delma. 


\section{RESUMO}

NARDI, M. S. Pesquisa de Leishmania sp. em flebótomos e mamíferos silvestres de fragmentos florestais na região do Pontal do Paranapanema, SP. [Survey of Leishmania sp in sandflies and mammals in forest fragments in the Pontal of Paranapanema region, SP]. 2010. 63p Dissertação (Mestrado em Ciências) - Faculdade de Medicina Veterinária e Zootecnia, Universidade de São Paulo, São Paulo, 2010.

As alterações ambientais antrópicas são os principais fatores de emergência ou reemergência de doenças infecciosas. A leishmaniose cutânea é uma doença que está relacionada, em caráter epidêmico, com episódios de desmatamento. No entanto, o caráter endêmico da doença ocorre quando o homem se encontra próximo de áreas florestais já colonizadas. $\mathrm{O}$ Pontal do Paranapanema é uma área onde ocorreu intenso desmatamento e a mata nativa remanescente está representada pelo Parque Estadual Morro do Diabo e alguns fragmentos florestais. Casos de leishmaniose cutânea em humanos são comuns na região, principalmente em áreas marginais de floresta. O objetivo deste trabalho foi realizar um levantamento da fauna flebotomínica e de mamíferos silvestres potencialmente reservatórios no Parque Estadual Morro do Diabo e alguns fragmentos da região, buscando avaliar se o tamanho do fragmento tem influência na ocorrência das espécies e na freqüência de Leishmania sp, através da técnica da PCR. Foram capturadas 26 espécies de flebótomos e sete espécies de mamíferos silvestres. O gênero Brumptomyia foi predominante em quase todas as áreas florestais, com exceção da borda do Parque, que apresentou dominância de Nyssomyia neivai. Os resultados das análises da PCR demonstraram quatro espécies de mamíferos portadores de Leishmania sp, Akodon cursor, Dasyprocta azarae, Didelphis albiventris e Oligoryzomys sp. As amostras de pools de flebotomíneos apresentaram resultados negativos. Não foi observada diferença significativa na freqüência de mamíferos infectados em relação ao tamanho da área florestal.

Palavras-chave: Pontal do Paranapanema. Flebotomíneos. Mamíferos Silvestres. Leishmania. Fragmentação florestal. 


\begin{abstract}
NARDI, M. S. Survey of Leishmania sp in sandflies and mammals in forest fragments in the Pontal of Paranapanema region, SP. [Pesquisa de Leishmania sp. em flebótomos e mamíferos silvestres de fragmentos florestais na região do Pontal do Paranapanema, SP]. 2010. 63f Dissertação (Mestrado em Ciências) - Faculdade de Medicina Veterinária e Zootecnia, Universidade de São Paulo, São Paulo, 2010.

Anthropogenic environmental changes are the main factors of emergence or reemergence of infectious diseases. Cutaneous leishmaniasis is a disease that is related, in an epidemic form, with episodes of deforestation. However, the endemicity of the disease occurs when the man is close to forest areas already colonized. The Pontal of Paranapanema is an area where massive deforestation has occurred and the remaining native forest is represented by the Morro do Diabo State Park and a few forest fragments. Cases of cutaneous leishmaniasis in humans are common in the region, especially in marginal areas of forest. The aim of this study was a survey of sand flies and mammals potentially reservoirs, in Morro do Diabo State Park and some fragments of the region, seeking to assess whether the fragment size has an influence on species occurrence and frequency of Leishmania, through the PCR technique. We captured 26 species of sandflies and seven species of wild mammals. The genus Brumptomyia was prevalent in almost all forest areas, except the edge of the park, which showed dominance of Nyssomyia neivai. The results of PCR analysis revealed four species of mammals suffering from Leishmania, Akodon cursor, Dasyprocta azarae, Didelphis albiventris and Oligoryzomys sp. Samples of sandfly pools tested negative. There was no significant difference in the frequency of infected mammals in relation to the size of the forest.
\end{abstract}

Keywords: Pontal of Paranapanema. Phlebotomines. Wild Mammals. Leishmania. Forest Fragmentation 


\section{SUMÁRIO}

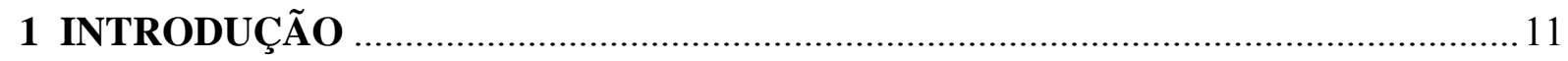

1.1 A LEISHMANIOSE E O PONTAL DO PARANAPANEMA....................................... 13

1.2 A FRAGMENTAÇÃO FLORESTAL E A LEISHMANIOSE.......................................15

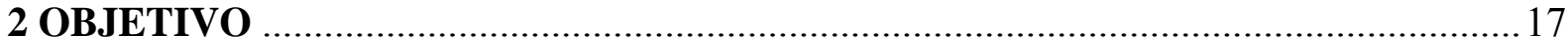

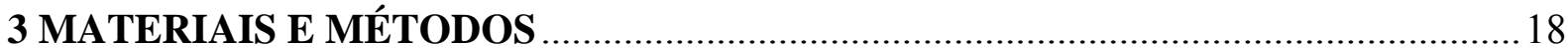

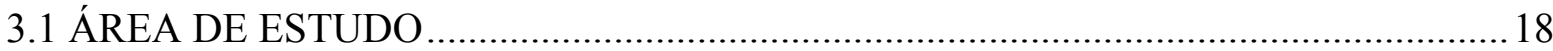

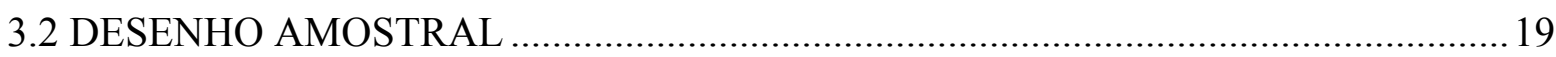

3.3 CAPTURA E COLETA DE MATERIAL DOS MAMÍFEROS .................................21

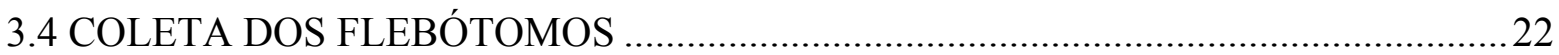

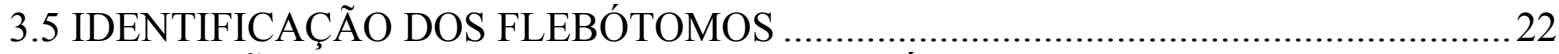

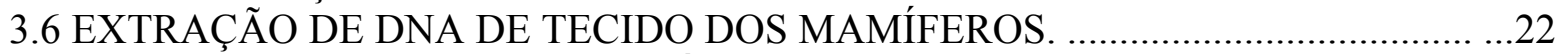

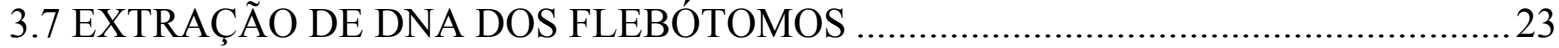

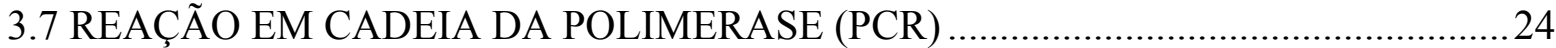

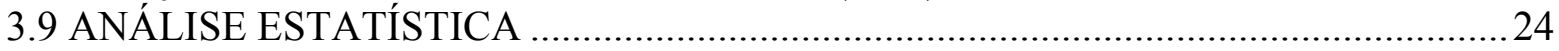

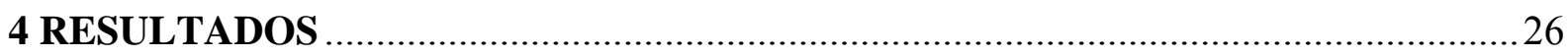

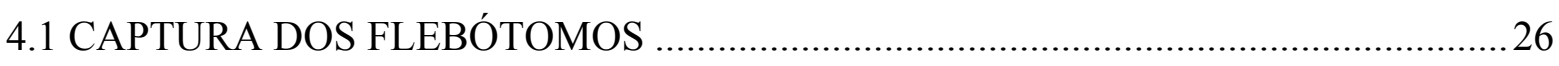

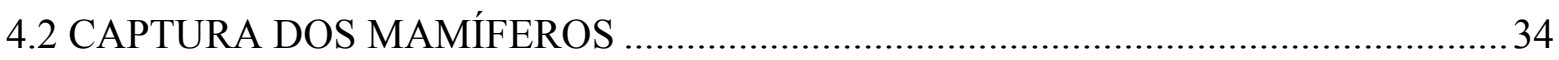

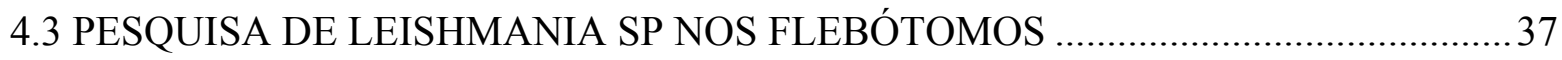

4.4 PESQUISA DE LEISHMANIA SP NO TECIDO DOS MAMÍFEROS .........................39

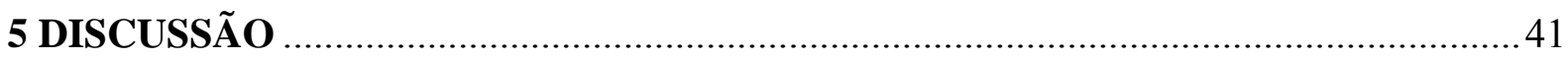

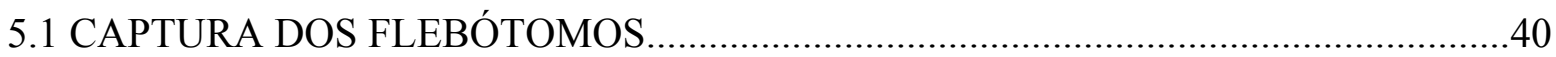

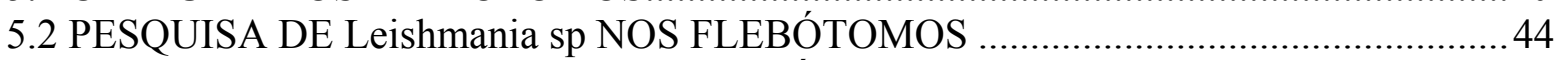

5.3 PESQUISA DE Leishmania sp NOS MAMÍFEROS ............................................... 46

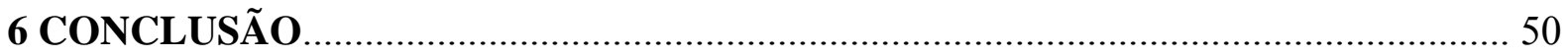

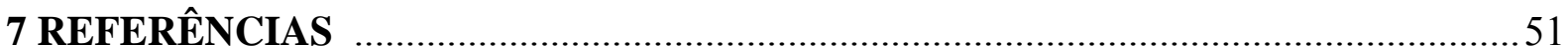

APÊNDICE 


\section{INTRODUÇÃO}

A Leishmaniose Tegumentar Americana é uma zoonose causada por protozoários do gênero Leishmania spp., considerada pela Organização Mundial da Saúde, uma das seis doenças infecciosas mais importantes devido sua alta incidência e o seu potencial de produzir deformidades, com grande impacto psicossocial no indivíduo (GONTIJO; CARVALHO, 2003; BRASIL, 2007).

Está presente em 88 países distribuídos nos continentes americano, africano, europeu e asiático, com registro anual de 1-1,5 milhões de casos, sendo que $90 \%$ dos casos notificados se encontram no Irã, Arábia Saudita, Índia, Paquistão, Brasil e Peru (BAILEY; LOCKWOOD, 2007; BRASIL, 2007).

Nas Américas, ocorre desde o sul dos Estados Unidos até o norte da Argentina, com exceção do Uruguai e Chile. No Brasil, a enfermidade ocorre em todos os Estados, com uma média anual no período de 1985 a 2005 de 28.568 casos autóctones registrados e incidência de 18,5 casos/100.000 habitantes. As regiões Norte e Centro-Oeste são as que apresentam maior incidência devido ao quadro de expansão da fronteira agropecuária e invasão das áreas naturais primitivas na região Amazônica (GOMES, 1992; GONTIJO; CARVALHO, 2003; BRASIL, 2007).

A doença apresenta basicamente três perfis epidemiológicos, sendo o primeiro puramente silvestre que ocorre em surtos epidêmicos, após episódios de derrubada das matas e exploração desordenada de madeira; o segundo, denominado silvestre modificado, ocorre em surtos epidêmicos sazonais na interface entre o peridomicílio e pequenos focos residuais de mata primária, onde o homem desenvolve atividades agrícolas; e o terceiro, periurbano, de forma endemo-epidêmica, endo ou peridomiciliar, com suspeita da participação de animais domésticos (BASANO; CAMARGO, 2004).

O agente da Leishmaniose é um protozoário da Ordem Kinetoplastida, família Tripanossomatidae, gênero Leishmania, que possui ciclo de vida heteroxênico, envolvendo um mamífero e um vetor artrópode. Nos mamíferos, o parasita adquire a forma amastigota, redonda e imóvel, e se reproduz obrigatoriamente dentro de células do sistema mononuclear fagocitário. No vetor, o parasita se encontra na luz do trato digestório, sob a forma promastigota, flagelada, distintas morfológica e bioquimicamente das amastigotas. A 
transmissão ocorre no momento do repasto sanguíneo realizado pela fêmea do vetor no mamífero (GONTIJO; CARVALHO, 2003; BASANO; CAMARGO, 2004).

A infecção do homem ocorre de maneira acidental, não tendo papel importante na manutenção do ciclo na natureza. As manifestações clínicas se apresentam sob as formas cutânea, caracterizada por lesões ulceradas, bordas elevadas e intenso tecido de granulação; muco-cutânea, com acometimento da mucosa e septo nasal e mucosa oral podendo levar a deformidades na face; e a forma difusa, caracterizada por lesões múltiplas, ulceradas, distribuídas por diversas partes do tegumento e distantes do sítio de inoculação primário (GONTIJO; CARVALHO, 2003).

Nas Américas, onze espécies são atualmente incriminadas na etiologia da doença. No Brasil, encontramos sete espécies, compreendendo os sub-gêneros Leishmania e Viannia. A L. (Leishmania) chagasi é a responsável pelo acometimento da forma visceral, em expansão pelo território brasileiro. A L. (Leishmania) amazonensis, L. (Viannia) guyanensis, L. (Viannia) lainsoni, L. (Viannia) shawi, L. (Viannia) naiffi e L. (Viannia) lindenberg são encontradas principalmente na bacia amazônica, tendo como hospedeiros mamíferos selvagens como roedores, marsupiais, primatas, xenarthras e carnívoros. A L. (Viannia) braziliensis está distribuída por todo o Brasil, porém, seus reservatórios selvagens não foram claramente definidos. O parasito já foi encontrado em roedores silvestres, sugerindo que os mesmos estejam incriminados na manutenção do ciclo silvestre e peridoméstico da doença (FORATTINI et al., 1972, 1973; LAINSON; SHAW, 2005; DE LIMA et al., 2002; BRANDÃO-FILHO, 2003; GONTIJO; CARVALHO, 2003; BASANO; CAMARGO, 2004; LAINSON; SHAW, 2005).

Os relatos da ocorrência de leishmaniose tegumentar em animais domésticos, como cães, equinos e muares, levantam a questão do papel destas espécies na manutenção do ciclo peridoméstico da doença (AGUILAR et al., 1984; FALQUETO et al., 1986; AGUILAR et al., 1989). No entanto, parece não existir evidências conclusivas (GOMES et al., 1990; TEODORO et al., 1993a; REITHINGER; DAVIES, 1999).

Os vetores das leishmanioses são os flebotomíneos (Ordem: Diptera, Família: Psychodidae, Sub-família: Phlebotominae), com cerca de 470 espécies descritas na América (GALATI, 2003). O flebotomíneo, conhecido popularmente como "mosquito-palha", "birigui", "cangalhinha" ou "tatuquira", possui como características morfológicas principais seu pequeno porte $(<0,5 \mathrm{~cm})$, corpo recoberto por pêlos, pernas e revestimento quitinoso delgados e asas que permanecem abertas quando o animal está em repouso. Tais características tornam estes dípteros sensíveis às variáveis ambientais o que se reflete no seu 
comportamento como, por exemplo, o hábito de se manterem em abrigos durante seu período de inatividade evitando a dessecação (FORATTINI, 1973).

O inseto adulto possui atividade predominantemente noturna e suas populações variam de forma sazonal, apresentando, na grande maioria das espécies, elevação da densidade nos meses mais quentes e úmidos (FORATTINI, 1954; TEODORO et al., 1993b; CONDINO et al., 1998).

Os criadouros dos flebotomíneos devem possuir algumas características imprescindíveis para o desenvolvimento das formas imaturas como, umidade, oxigênio, matéria orgânica em decomposição e pouca incidência de luz. Em condições naturais, larvas e pupas já foram encontradas em troncos e raízes de árvores, tocas de animais, fendas de rochas, no solo florestal e folhas caídas. As capturas de formas imaturas em chiqueiros, galinheiros, troncos e raízes de árvores frutíferas do peridomicílio refletem a adaptação de algumas espécies ao ambiente antropizado (FORATTINI, 1953; FORATTINI, 1973).

No caso da leishmaniose tegumentar no Estado de São Paulo, após intensa destruição da Mata Atlântica, os focos da doença permaneceram em caráter endêmico, diferentemente do que foi publicado por Sampaio (1951), que sugeriu uma tendência ao desaparecimento após a derrubada das matas (GOMES, 1992; TOLEZANO, 1994).

Espécies como Nyssomyia intermedia, Nyssomyia neivai, Nyssomyia whitmani, Migonemyia migonei, Pintomyia pessoai e Pintomyia fischeri, são freqüentemente encontradas em ambientes peridomiciliares e domiciliares com incidência da doença. Tais espécies já foram encontradas naturalmente infectadas, sendo incriminadas vetoras da leishmaniose tegumentar no Estado de São Paulo e responsáveis pela característica endêmica da leishmaniose cutânea, denotando grande importância em saúde pública (PESSOA; COUTINHO, 1941; TEODORO et al., 1991; PETERSON; SHAW, 2003; CAMARGONEVES, 2002).

\subsection{A LEISHMANIOSE E O PONTAL DO PARANAPANEMA}

A cobertura florestal original predominante no território paulista era a Mata Atlântica. Durante a ocupação humana, ao longo dos anos, este bioma foi sendo reduzido e fragmentado, e suas áreas remanescentes significativas se encontram nos limites do Parque Estadual da 
Serra do Mar, no Vale do Ribeira e no Pontal do Paranapanema, extremo oeste do Estado de São Paulo (SOS MATA ATLÂNTICA; INPE, 2002).

No Pontal, a fragmentação florestal ocorre principalmente por motivos políticos e sócio-econômicos. Em 1942, o governo do Estado de São Paulo criou uma Unidade de Conservação chamada "Grande Reserva do Pontal do Paranapanema”, para proteger 247.000 hectares de Mata Atlântica na região. Por decreto, o então governador Adhemar de Barros, em 1966, aboliu a grande reserva e durante as cinco décadas seguintes, sua cobertura florestal foi sendo substituída por pastagens para pecuária extensiva e por plantios de canade-açúcar (FERRARI LEITE, 1998).

Durante a colonização do Pontal, entre as décadas de 40 e 60, período em que houve intenso desmatamento, os casos de leishmaniose se apresentaram de forma epidêmica, com uma prevalência de $10-20 \%$, chegando até a $30-40 \%$ da população rural. Diante destes dados, Pessoa e Pestana (1940) colocaram a região do Pontal dentro da classificação denominada "zona de alta endemicidade" do Estado de São Paulo.

Neste período, Forattini (1954) atribuiu ao Phebotomus intermedius o papel mais importante na transmissão da leishmaniose na região. O mesmo autor, mais tarde, após a captura de 928 mamíferos selvagens nas florestas do Pontal, dentre roedores, marsupiais, primatas e carnívoros, encontrou flagelados compatíveis com Leishmania sp em três roedores, sendo, uma cutia (Dasyprocta azarae), uma paca (Agouti paca) e um rato-dataquara (Kannabateomys amblyonyx) (FORATTINI, 1960).

Posteriormente, com a chegada do Movimento dos Trabalhadores Sem-Terra (MST), a região do Pontal ficou caracterizada por intensos conflitos fundiários protagonizados pelo MST e os grandes latifundiários da região. Após o estabelecimento do Movimento, uma nova dinâmica de ocupação trouxe à região uma paisagem onde os fragmentos florestais estão circundados por assentamentos rurais da reforma agrária (VALLADARES-PADUA et al., 2002).

Nesses terrenos familiares praticam-se predominantemente atividades agropastoris para subsistência, com assentados mantendo grande variedade de animais domésticos de produção para consumo próprio ou animais domésticos de companhia (SCHLOEGEL et al., 2005). Este modelo de ocupação coloca o homem próximo dos ambientes florestais primitivos e favorece a transmissão de zoonoses, como a Leishmaniose Tegumentar Americana. 
Atualmente, os casos humanos da leishmaniose tegumentar se apresentam em caráter endêmico. Quase quarenta anos depois do estudo realizado por Forattini (1954), na mesma área do município de Teodoro Sampaio, em área rural peridomiciliar, próximo à borda do Parque Estadual Morro do Diabo, Condino et al. (1998) observaram novamente a dominância de Lutzomia intermedia, mesmo após a transformação da paisagem.

\subsection{A FRAGMENTAÇÃO FLORESTAL E A LEISHMANIOSE}

Segundo Patz et al. (2000), as alterações antrópicas do ambiente natural estão entre os principais fatores que influenciam na ecologia das doenças infecciosas, resultando na emergência de novas doenças e modificação do modo de transmissão em suas áreas de ocorrência, estando diretamente relacionados com alterações na composição das espécies envolvidas na transmissão.

Dentre essas alterações, a fragmentação florestal é uma das principais causas de modificação na composição de espécies de uma comunidade. O isolamento causado pela fragmentação dos habitats resulta em maior suscetibilidade à extinção e redução na biodiversidade, estando relacionados a inúmeros fatores como diminuição no tamanho da população efetiva, menores taxas de migração e dispersão, maior perda da variabilidade genética e redução nas interações ecológicas (TERBORGH, 1992; BROWN; BROWN, 1994; CHIARELLO, 1999).

Além disso, observa-se uma elevação da relação borda-interior, ocasionando aumento da penetração da luz solar, maior intensidade de vento, elevação da temperatura, aumento da evapotranspiração e a diminuição da umidade relativa do solo e do ar, sofrendo grande influência das atividades do entorno. Estes efeitos mudam a composição das espécies, favorecendo apenas aquelas que se adaptam a estas novas condições. À este fenômeno, dá-se o nome de "Efeito de Borda" (MURCIA, 1995; TURNER, 1996; STEVENS; HUSBAND, 1998; PACIÊNCIA; PRADO, 2004).

Segundo Ostfeld e Kessing (2000), comunidades mais diversas podem diminuir o risco de epizootias e epidemias ao impedir a dominância de espécies consideradas vetoras ou

reservatórias de determinadas doenças. Desta forma, quando tratamos de ambientes fragmentados, sob efeito de borda, em que a diversidade de espécies é pobre e o vetor e/ou 
reservatório competentes são generalistas e antropofílicos, se adaptaram e se beneficiaram à condição proporcionada pela fragmentação, o risco de infecção para o homem pode ser maior, como foi observado nos Estados Unidos, com a Doença de Lyme (OSTFELD; KESSING, 2000; ALLAN et al., 2003; LOGIUDICE et al., 2003). Muitas vezes, o modelo de ocupação aproxima o ser humano das áreas florestais, favorecendo a transmissão de zoonoses silvestres emergentes ou reemergentes, como as hantaviroses, arboviroses, doenças transmitidas por carrapatos e as leishmanioses (DASZAK et al., 2007).

No que se refere à leishmaniose tegumentar, tratada anteriormente como restrita ao ambiente puramente silvestre, fica claro que houve uma adaptação dos vetores após a transformação da paisagem. A detecção da Lesihmania (Viannia) braziliensis em roedores e marsupiais comuns em áreas florestais degradadas e antropizadas, assim como a frequência elevada de espécies de flebótomos com capacidade vetorial, demonstram a adaptação dos atores envolvidos no ciclo da leishmaniose em ambientes florestais modificados.

Gomes (1992) coloca que devido ao caráter florestal da doença, o desequilíbrio ambiental poderia servir como barreira ecológica aos vetores e reservatórios naturais do agente, com marcante redução na sua incidência. No entanto, frente à devastação, para garantir seu ciclo vital, a Leishmania (Viannia) braziliensis se adaptou a estrutura biótica e abiótica do ambiente florestal residual e peridomiciliar com condições de manutenção da sua infecciosidade, como podemos constatar pelos focos leishmanióticos distribuídos na região Sudeste.

Diante do contexto atual de degradação da Mata Atlântica na região do Pontal, onde os remanescentes estão representados por fragmentos florestais e estão sendo ocupados em seu entorno por assentamentos da reforma agrária, estudos que avaliem os efeitos da fragmentação sobre a fauna flebotomínica e as comunidades de pequenos mamíferos, associada a pesquisa de Leishmania sp. nesses animais, contribuirão com o esclarecimento dos fatores ecológicos que poderiam estar envolvidos na manutenção do status endêmico e nas eventuais epizootias da doença, auxiliando nas tomadas de decisão em relação as medidas de controle e prevenção. 


\section{OBJETIVO}

O objetivo principal deste trabalho é investigar a diversidade da fauna flebotomínica e de pequenos mamíferos silvestres em fragmentos florestais na região do Pontal do Paranapanema e verificar se existe a associação entre fragmentação florestal e a frequência de Leishmania spp nestas espécies. 


\section{MATERIAIS E MÉTODOS}

Foram realizadas capturas de pequenos mamíferos silvestres e de flebotomíneos em nove áreas, identificação das espécies encontradas, coleta de amostra dos mamíferos e posteriormente a pesquisa de Leishmania spp. do material obtido através da técnica de PCR.

\section{1 ÁREA DE ESTUDO}

A região do Pontal do Paranapanema está localizada no extremo oeste do Estado de São Paulo. Representada pelos municípios de Teodoro Sampaio, Euclides da Cunha Paulista, Rosana, Presidente Epitácio e Marabá Paulista, tem como limite sul o Rio Paranapanema e oeste o Rio Paraná.

Situa-se na província morfológica do Planalto Ocidental de São Paulo, caracterizada pela presença de colinas amplas, baixa declividade (menos de 15\%) e interflúvios com mais de $4 \mathrm{Km}^{2}$ (PONÇANO et al., 1981). O solo é constituído a partir das formações do grupo Bauru, sendo o tipo predominante o Latossolo, tendo como principais características a elevada concentração de areias, fertilidade natural baixa, boa permeabilidade e drenagem excessiva (YAMAMOTO; BERTOLINI; MURAMOTO, 1998).

O clima da região apresenta uma alternância de período seco e frio (entre maio e agosto, com média de $17^{\circ} \mathrm{C}$ em junho) e período quente e úmido (entre novembro e fevereiro, com média de $25^{\circ} \mathrm{C}$ ). As chuvas se concentram nos meses de dezembro a janeiro e a precipitação média anual varia de 1.200 a 1.400 mm (YAMAMOTO; BERTOLINI; MURAMOTO, 1998).

Segundo a classificação de Veloso et al. (1991), a vegetação do Pontal é denominada Floresta Estacional Semidecidual, situada dentro do Domínio Florestal Atlântico. Este tipo de floresta sofre influência de duas estações climáticas; tropical, com chuvas de verão intensas seguidas por estiagem acentuadas; subtropical, sem período seco, mas com seca fisiológica provocada pelo frio do inverno. A Floresta Atlântica de Interior é caracterizada pela ausência de coníferas e pela perda parcial de folhas em decorrência da baixa precipitação pluviométrica no inverno. 
A cobertura vegetal original sofreu intensa redução ao longo dos últimos cinquenta anos. Atualmente, os fragmentos de mata remanescentes totalizam 21.000 hectares, juntamente com os 36.000 hectares de floresta do Parque Estadual Morro do Diabo (DITT, 2002). Em 1991, cerca de $71 \%$ da paisagem do Pontal era composta por pastagens (YAMAMOTO; BERTOLINI; MURAMOTO, 1998). Atualmente, com a instalação de novas usinas do setor sucroalcooleiro na região, essas áreas de pastagens estão sendo substituídas pelo cultivo de cana-de-açúcar.

\subsection{DESENHO AMOSTRAL}

O projeto teve como desenho amostral seis fragmentos florestais e três áreas do Parque Estadual Morro do Diabo. A captura de mamíferos foi realizada trimestralmente em cada área. As capturas dos flebótomos foram realizadas simultaneamente, nos meses de novembro e dezembro de 2008, janeiro, fevereiro, março e maio de 2009. Desta forma foram selecionados três fragmentos pequenos ( $<100$ hectares), três grandes (1000 hectares) e três áreas dentro do Parque Estadual Morro do Diabo (36000 hectares). As unidades amostrais estão apresentadas na figura 1 e caracterizadas na tabela 1. 


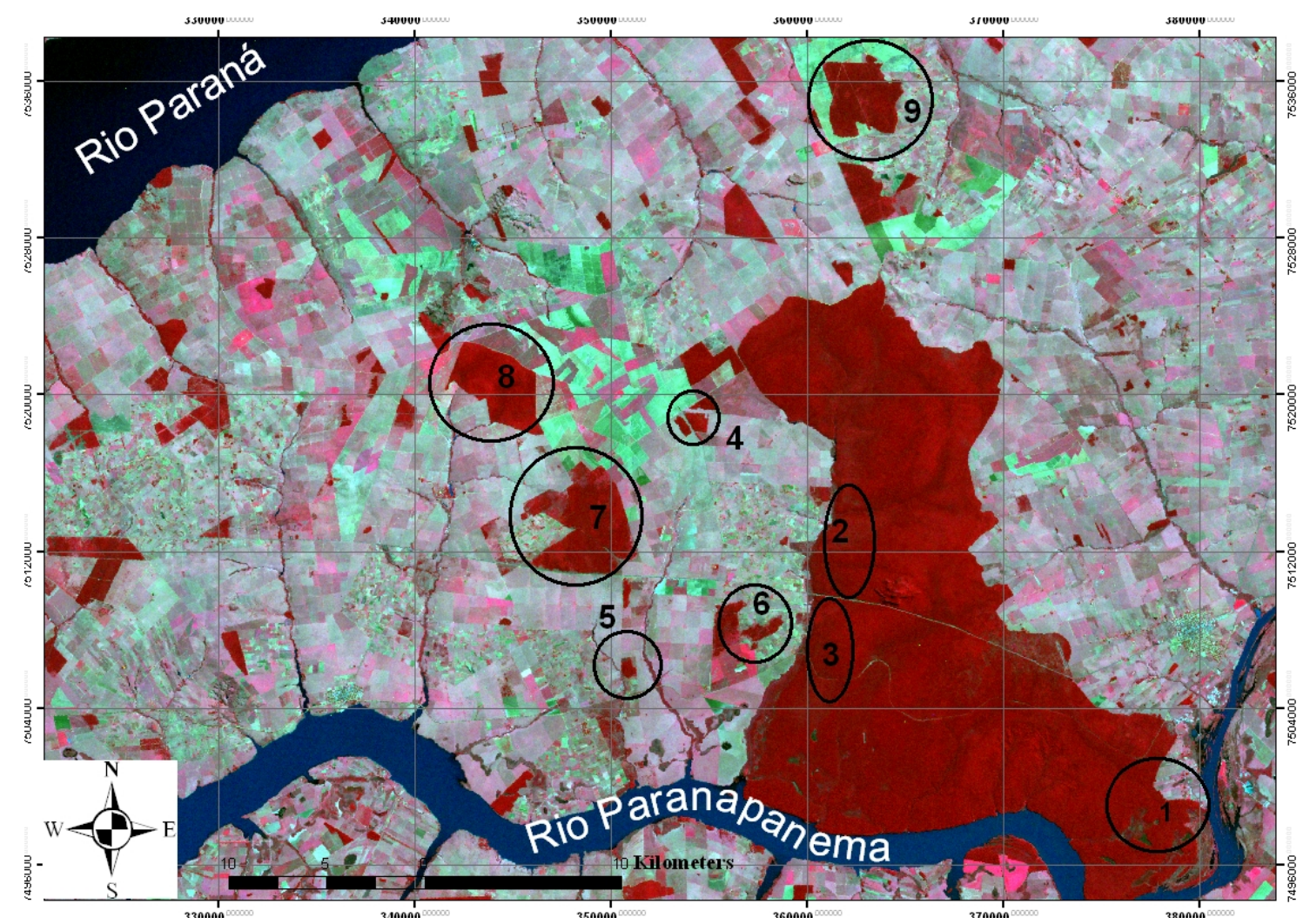

Figura 1 - Fragmentos florestais da região do Pontal do Paranapanema (em vermelho) e as áreas selecionadas do projeto - Teodoro Sampaio, SP - 2009

Tabela 1-Características das áreas amostrais na região do Pontal do Paranapanema - Teodoro Sampaio, SP - 2009

\begin{tabular}{cllc}
\hline Número* & Nome & Tamanho & $\begin{array}{l}\text { Área } \\
\text { (ha) }\end{array}$ \\
\hline 1 & PEMD - Perobeira & Controle & 35830,4 \\
2 & PEMD - Estreito de & Controle & 35830,4 \\
& Cima & & \\
3 & PEMD - Estreito de & Controle & 35830,4 \\
& Baixo & & \\
4 & Copacabana & Pequeno & 80,0 \\
5 & Rosanela & Pequeno & 80,0 \\
6 & Ribeirão Bonito & Pequeno & 134,0 \\
7 & Tucano & Grande & 1850,0 \\
8 & Ponte Branca & Grande & 1282,3 \\
9 & Água Sumida & Grande & 1154.9 \\
\hline
\end{tabular}

*numeração refere-se ao mapa apresentado na figura 1 
Para deslocamento entre os fragmentos, o veículo utilizado foi um Volkswagen Kombi ano 2000, gentilmente cedido pelo Instituto de Pesquisas Ecológicas, localizado na cidade de Teodoro Sampaio.

\subsection{CAPTURA E COLETA DE MATERIAL DOS MAMÍFEROS}

As campanhas de captura dos mamíferos foram realizadas nos meses de agosto, outubro, novembro e dezembro de 2008, janeiro, fevereiro, março e junho de 2009. Cada campanha teve a duração de quatro noites e as armadilhas usadas foram do tipo Sherman (tamanho 28x14x12 cm) e do tipo gaiola ( $44 \times 20,5 \times 21,5 \mathrm{~cm}$ ). As mesmas foram instaladas próximas dos locais de captura dos flebótomos e iscadas com uma mistura de banana, doce de amendoim, fubá e calabresa (ROCHA, 2004).

Foram estabelecidos quatro transectos paralelos, sendo, o primeiro na borda, o segundo à cem metros e os outros a trezentos e quinhentos metros da margem da floresta. Cada transecto continha dez pontos de captura, distantes vinte e cinco metros entre si (ROCHA, 2004). Em cada ponto foi instalada uma armadilha do tipo gaiola no chão e, a cada três pontos, uma do tipo Sherman.

Para coleta do material, os marsupiais foram contidos fisicamente com luvas de raspa de couro e os roedores anestesiados utilizando a associação de quetamina/ xilazina/ atropina na dosagem de $50 \mathrm{mg} / \mathrm{Kg}, 5 \mathrm{mg} / \mathrm{Kg}$ e $0,044 \mathrm{mg} / \mathrm{Kg}$ respectivamente (PESSOA, 2006). O procedimento envolveu pesagem, sexagem, biometragem e inspeção quanto à presença de lesão em pele ou alopecia. Nos pequenos roedores, o sangue foi coletado do seio retro-orbital utilizando tubo capilar heparinizado (ROCHA, 2004; RUEDAS et al., 2004). Nos animais maiores o sangue foi coletado da veia caudal, femoral ou jugular e depositado em tubo tipo Vacuntainner ${ }^{\circledR}$ com e sem Citrato de Sódio. Foram colhidas amostras de pele da ponta da orelha e base da cauda ou de locais que possuíam alguma lesão ou alopecia, utilizando um bisturi estéril (OLIVEIRA et al., 2005). O fragmento foi armazenado em microtubo contendo tampão TNE (Tris, EDTA e $\mathrm{NaCl}$ ) e congelado a $-20^{\circ} \mathrm{C}$ para análise. Após estes procedimentos, os animais receberam uma marcação com brincos de metal ("ear tags") na orelha, possuindo numeração individual. Paralelamente, foram colhidas fezes para pesquisa de endoparasitas e de carrapatos para identificação e pesquisa de ricketssioses na Faculdade de Medicina Veterinária e Zootecnia da Universidade de São Paulo. 


\subsection{COLETA DOS FLEBÓTOMOS}

As coletas foram iniciadas em novembro de 2008 e realizadas durante os meses de novembro, dezembro, janeiro, fevereiro e março. A captura foi realizada utilizando armadilhas luminosas tipo CDC (Center for Disease Control) instaladas a aproximadamente um metro do solo, das 18:00 às 06:00. Cada área possuiu quatro estações de captura, sendo uma na borda e três no interior, dispostas a 100, 300 e 500 metros da área marginal.

\subsection{IDENTIFICAÇÃO DOS FLEBÓTOMOS}

Os insetos capturados em campo foram armazenados em álcool 70\% e encaminhados para identificação na Faculdade de Saúde Pública de São Paulo, utilizando a chave proposta por Galati (2003). Para a identificação das espécies, primeiramente, foi realizada a clarificação dos insetos, segundo a técnica descrita por Forattini (1973). Os machos foram totalmente clarificados, porém as fêmeas, apenas a cabeça e a parte terminal do abdômen contendo as espermatecas. O restante do corpo das fêmeas foi utilizado para a pesquisa de Leishmania sp. através da técnica de PCR.

\subsection{EXTRAÇÃO DE DNA DE TECIDO DOS MAMÍFEROS}

O protocolo para extração de DNA de tecidos foi realizado seguindo metodologia in house, de acordo com protocolo descrito por Ausubel et al. (1999). Este protocolo é adequado para a extração de DNA de células de mamíferos. Sendo a forma parasitária de Leishmania sp uma estrutura unicelular com estrutura de envoltório similar à de células de mamíferos, o protocolo ora empregado demonstrou-se adequado.

Primeiramente foi realizada a lavagem da amostra com tampão TE (Tris EDTA) pH 8.0, para que o material ficasse livre de hemoglobina, inibidor da PCR. Este processo consistiu no acréscimo de TE, homogeneização em vórtex, centrifugação por $12.000 \mathrm{~g} \mathrm{x}$ durante 5 minutos e descarte do sobrenadante repetidas vezes até que o sedimento perdesse a 
coloração vermelho escura e o sobrenadante ficasse bem claro. Posteriormente, realizamos a lise celular do material adicionando $500 \mu \mathrm{L}$ de tampão TNE-SDS (10mM TrisHCl, pH 8,0, $100 \mathrm{mM} \mathrm{NaCl}, 25 \mathrm{mM}$ EDTA pH 8,0, $1 \%$ SDS $)$ e $10 \mu \mathrm{L}$ de proteinase $K(20 \mathrm{mg} / \mathrm{ml})$, deixando incubar overnight a $37^{\circ} \mathrm{C}$.

Para purificação do material, centrifugamos a mistura obtida a $10.000 \times \mathrm{g}$ durante $3 \mathrm{a}$ 5 minutos, adicionamos $90 \mu \mathrm{l}$ de $\mathrm{NaCl} 5 \mathrm{M} \mathrm{pH} 8.0,80 \mu 1$ de $\mathrm{CTAB}$ pré-aquecido a $65{ }^{\circ} \mathrm{C}$, homogeneizamos e incubamos por 30 minutos à $65^{\circ} \mathrm{C}$. Após a incubação, adicionamos $675 \mu 1$ de clorofórmio, homogeneizamos novamente e centrifugamos a amostra a $12.000 \mathrm{x}$ g por 5 minutos. Posteriormente, recolhemos a fase aquosa superior em outro microtubo de $1,5 \mathrm{ml} \mathrm{e}$ adicionamos igual volume de propanol absoluto, deixando precipitar overnight. Centrifugamos o material a $12.000 \mathrm{x}$ g por 30 minutos, desprezamos o sobrenadante vertendo o tubo cuidadosamente e ressuspendemos o sedimento em Etanol 70\%. Novamente centrifugamos a suspensão a 12.000 x g por 15 minutos, desprezamos o sobrenadante e os deixamos secar invertidos sobre um papel absorvente. O sedimento de DNA foi ressuspendido em $30 \mu \mathrm{l}$ de TE, homogeneizado em vórtex, incubado a $56^{\circ} \mathrm{C}$ por 10 minutos e novamente homogeneizado. Após todo este processo, centrifugamos este material a $12.000 \mathrm{x}$ g por 1 minuto e estocamos a $-20^{\circ} \mathrm{C}$ para realização da pesquisa de Leishmania sp..

As amostras extraídas foram avaliadas por espetrofotometria de luz UV, empregandose o espectrofotômetro Beckman DU 600. Foram empregadas leituras em comprimentos de onda de 260 e $280 \mathrm{~nm}$, sendo consideradas amostras com grau de pureza adequada para técnica de PCR aquelas que apresentassem razão de absorbância A260/A280 entre 1,8 e 2,0.

\subsection{EXTRAÇÃO DE DNA DOS FLEBÓTOMOS}

Foram formados pools de 1-20 indivíduos, separados de acordo com o fragmento de captura e a espécie. Para extração do DNA dos flebótomos foi utilizado o DNEasy Blood \& Tissue Kit ${ }^{\circledR}$ (Qiagem) de acordo com as instruções do fabricante. Na última etapa, foi utilizado $50 \mu 1$ do buffer de eluição do DNA, para maior concentração do DNA total obtido.

Devido a semelhança dos caracteres morfológicos que dificultam a distinção da espécie nas fêmeas do gênero Brumptomyia sp, foi preconizado a formação de pool por gênero destes indivíduos. As amostras extraídas dos pools de flebotomíneos foram quantificadas em aparelho BioPhotometer Plus Eppendorf $₫(\lambda 260 / 280)$. 


\subsection{REAÇÃO EM CADEIA DA POLIMERASE (PCR)}

O protocolo de amplificação empregado utilizou $45 \mu \mathrm{L}$ de mix de reagentes $(24,2 \mu \mathrm{L}$ $\mathrm{H} 2 \mathrm{O} \mathrm{mQ}, 8 \mu \mathrm{L}$ dNTP $(1,25 \mathrm{mM}), 3 \mu \mathrm{L}$ de cada primer $(10 \mathrm{pmol} / \mu \mathrm{L}), 5 \mu \mathrm{L}$ de $10 \mathrm{X}$ PCR Buffer, $1,5 \mu \mathrm{L} \mathrm{MgCl}(50 \mathrm{mM}), 0,5 \mu \mathrm{L}$ taq Polimerase e $5 \mu \mathrm{L}$ de amostra, resultando no total de $50 \mu \mathrm{L}$ em cada microtubo que foi levado à máquina termocicladora. Os primers utilizados foram descritos por Rodgers et al. (1990), que amplificam um fragmento de $120 \mathrm{pb}$ do cinetoplasto de Leishmania sp..

O termociclador utilizado foi MyGene ${ }^{\mathrm{TM}}$ Series Gradient Thermal Cycler Model MG96G Long Gene ${ }^{\circledR}$ Scientific instruments Co, Ltd Hangzhou, Zhejiang China. Cada ciclo era composto de min30s a $94^{\circ} \mathrm{C}, 30 \mathrm{~s}$ a $94^{\circ} \mathrm{C}, 45 \mathrm{~s}$ a $56^{\circ} \mathrm{C}, 45 \mathrm{~s}$ a $72^{\circ} \mathrm{C}$, repetido 39 vezes. Após as repetições, era mantido a $72^{\circ} \mathrm{C}$ por $5 \mathrm{~min}$ e finalmente levado a $15^{\circ} \mathrm{C}$. Os produtos de $\mathrm{PCR}$ foram separados por eletroforese em gel de agarose 2,0\% em cuba horizontal, imersos em tampão TBE (Tris-Borato 0,045M; EDTA 1mM). A fotodocumentação dos géis com os fragmentos amplificados foi com auxílio da câmera Image Master GE Healthcare. Os controles positivos utilizados foram obtidos a partir de amostras de L. (Viannia) braziliensis, L. (Leishmania) chagasi e L. (Leishmania) amazonensis provenientes de cultura em laboratório, cedidos pela FIOCRUZ. Como controle negativo, utilizamos água-Mili Q. Não foi utilizado nenhum controle endógeno.

\subsection{ANÁLISE ESTATÍSTICA}

Para análise de riqueza em cada área, foram utilizados o número total de espécies e o Índice de Margalef (1949), através da fórmula:

$$
D_{m}=\frac{s-1}{\ln N}
$$

Onde:

$s=$ número de espécies de flebotomíneos capturadas em um determinado período e ponto;

$N$ = número de espécimes capturados neste mesmo período e tempo. 
Para o cálculo da Diversidade foi utilizado o Índice de Shannon, que é dado pela fórmula:

$H=-\sum_{i=1}^{S} p_{i} \ln p_{i}$

Onde:

$p_{i}=$ proporção de indivíduos da espécie $i$ em relação ao total de indivíduos.

$S$ = número de espécies coletadas.

A abundância numérica e a distribuição espacial das espécies de flebotomíneos encontradas nos vários tipos de ecótopos de um determinado ponto e período foram estimadas por meio do Índice de Abundância de Espécies Padronizado (IAEP), conforme Roberts e Hsi (1979), calculado pela fórmula:

$$
I A E=\frac{a R j}{K}
$$

Onde:

$a=$ número de pontos de captura em que a espécie esteve ausente $\mathrm{x} \boldsymbol{c}$;

$c=$ para cada sítio de captura, deve-se distribuir as espécies em postos, que variam de 1 a $\mathbf{n}$ (atribuindo-se o valor 1 para a espécie mais frequente). O c compreenderá o maior valor de $\mathbf{n}$ obtido, considerando todos os sítios, acrescido de 1;

$R j=$ somatória das posições de cada espécie;

$K=$ número de pontos de captura.

A conversão dos valores obtidos em uma escala entre zero e 1 foi obtida pela fórmula:

$I A E P=\frac{c-I A E}{c-1}$

Neste índice, o valor 1 corresponde à espécie mais abundante e portanto, quanto mais o valor se aproximar de zero, menor a abundância da espécie.

As medidas de equitabilidade ou dominância foram obtidas pelos Índices de Pielou (J) e de Buzas \& Gibson (E) (HAYEK; BUZAS, 1997).

As proporções de mamíferos positivos oriundos de fragmentos foram comparadas com a proporção de animais positivos oriundos do parque através do teste de $\chi^{2}$. 


\section{RESULTADOS}

\subsection{CAPTURA DOS FLEBÓTOMOS}

Ao todo foram capturados 1960 flebótomos, sendo 1045 (53,31\%) fêmeas e 915 machos (46,68\%), dentre 26 espécies. O esforço de captura foi de 240 horas trabalhadas por área amostral. $\mathrm{O}$ cálculo foi feito da seguinte forma:

12 (horas/ dia) x 4 (número de armadilhas) x 5 (número de campanhas de captura, um dia por campanha)

No gênero Brumptomyia sp, não foi possível a identificação das fêmeas até o nível de espécie, tendo em vista que parte do material com estruturas que possibilitariam tal distinção foram utilizadas para a pesquisa de Leishmania sp através da PCR e/ou seus apêndices estavam danificados. A identificação foi realizada apenas nos machos e a proporção de espécies encontradas, de um total de 244 indivíduos, foram Brumptomyia brumpti (89,75\%), Brumptomyia avellari (8,19\%), Brumptomyia cunhai (1,23\%), Brumptomyia galindoi (0,4\%) e Brumptomyia guimaraesi (0,4\%). Para análise dos dados, estas espécies foram agrupadas segundo o gênero.

Do total das espécies capturadas, Nyssomyia neivai foi representada com o maior número de indivíduos, seguidas pelas espécies do gênero Brumptomyia sp. e Pintomyia pessoai (Figura 2). Segundo Shimabukuro (2007), foram capturadas duas espécies sem descrição anterior de ocorrência no Estado de São Paulo, são elas Psathiromyia (Forattiniella) campograndensis e Evandromyia teratodes. 


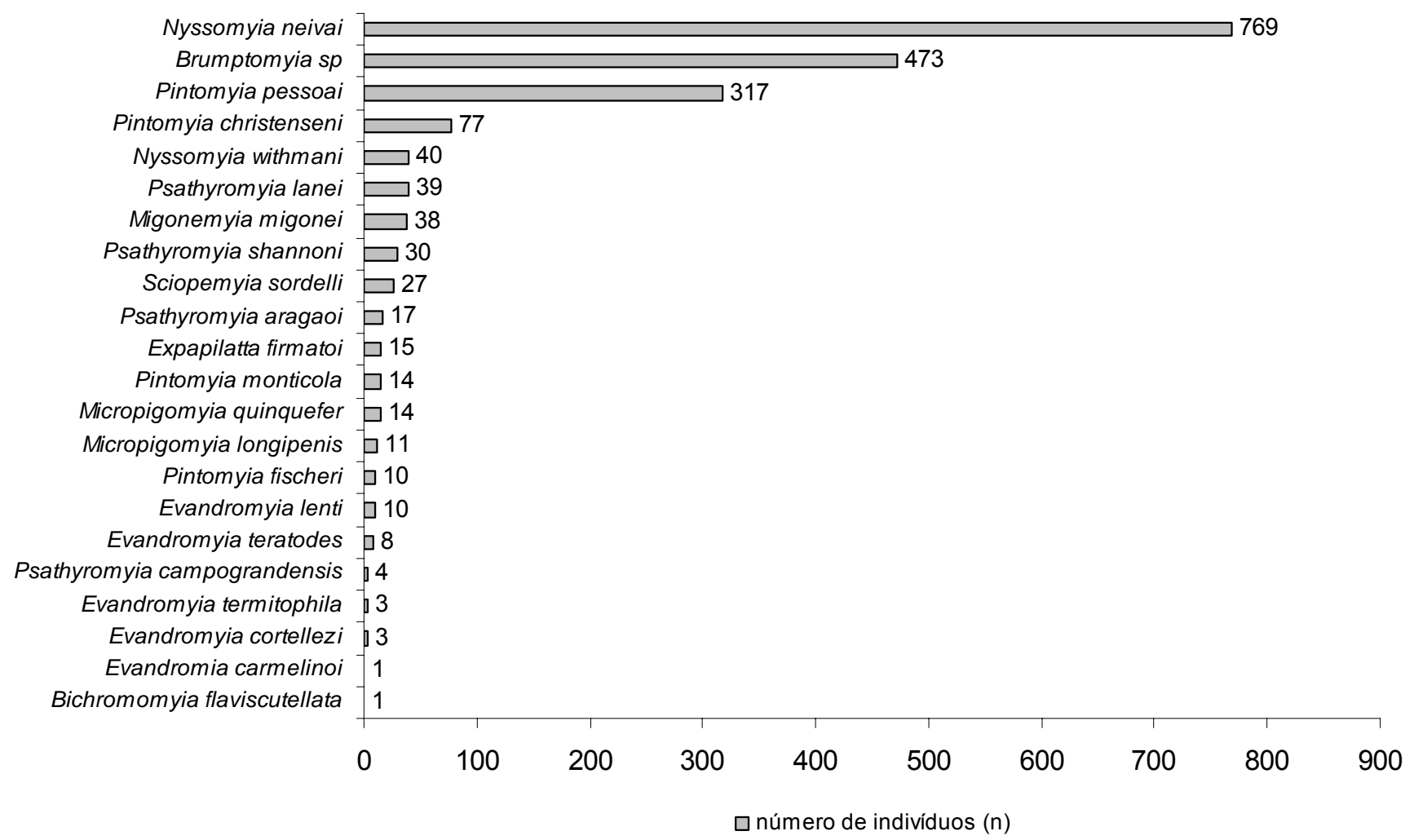

Figura 2 - Espécies de flebotomíneos capturados e o número de espécimes, do total de capturas, no Pontal do Paranapanema

Considerando apenas os dados oriundos do Parque Estadual Morro do Diabo, foram capturadas 24 espécies, sendo Nyssomyia neivai aquela com maior número de capturas (realizadas predominantemente no ponto instalado na borda desta área). Em seguida as principais espécies foram Pintomyia pessoai e as espécies do gênero Brumptomyia sp. Em relação aos fragmentos, as espécies do gênero Brumptomyia sp foram predominantes, seguidas por Pintomyia pessoai e Pintomyia christenseni. O número de indivíduos, o sexo, as espécies e os devidos locais de captura estão listados nas tabelas 2 e 3. 
Tabela 2 - Espécies de flebotomíneos e número de indivíduos capturados segundo sexo e fragmento de captura do Município de Teodoro Sampaio, SP - 2008-2009

\begin{tabular}{|c|c|c|c|c|c|c|c|c|c|c|c|c|c|c|c|c|c|c|}
\hline \multirow{3}{*}{ Espécies } & \multicolumn{18}{|c|}{ Local } \\
\hline & \multicolumn{2}{|c|}{ PER } & \multicolumn{2}{|c|}{ EC } & \multicolumn{2}{|c|}{ EB } & \multicolumn{2}{|c|}{ PB } & \multicolumn{2}{|c|}{ TC } & \multicolumn{2}{|c|}{ AS } & \multicolumn{2}{|c|}{$\mathbf{R B}$} & \multicolumn{2}{|c|}{ ROS } & \multicolumn{2}{|c|}{ COP } \\
\hline & $\pi$ & 9 & 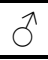 & $q$ & $\widehat{\delta}$ & 9 & $\pi$ & $q$ & $\delta^{\lambda}$ & q & $\delta$ & $q$ & $\hat{0}$ & 9 & $\widehat{\delta}$ & $q$ & $\delta$ & q \\
\hline Brumptomyia sp & - & 16 & - & 16 & - & 26 & - & 26 & - & 7 & - & 6 & - & 49 & - & 51 & - & 39 \\
\hline B. avellari & - & - & - & - & - & - & 3 & - & - & - & - & - & 5 & - & 7 & - & 5 & - \\
\hline B. brumpti & 5 & - & 19 & - & 14 & - & 41 & - & 1 & - & 6 & - & 41 & - & 81 & - & 15 & - \\
\hline B. cunhai & 2 & - & - & - & - & - & - & - & - & - & - & - & 1 & - & - & - & - & - \\
\hline B. galindoi & 1 & - & - & - & - & - & - & - & - & - & - & - & - & - & - & - & - & - \\
\hline B. guimaraesi & - & - & 1 & - & - & - & - & - & - & - & - & - & - & - & - & - & - & - \\
\hline B. flaviscutellata & - & - & - & 1 & - & - & - & - & - & - & - & - & - & - & - & - & - & - \\
\hline Ev. carmelinoi & - & - & - & 1 & - & - & - & - & - & - & - & - & - & - & - & - & - & - \\
\hline Ev. cortellezi & - & - & 1 & 1 & - & - & - & - & - & - & - & - & - & 1 & - & - & - & - \\
\hline Ev. lenti & 1 & - & - & - & 2 & 3 & 1 & - & - & - & - & - & 1 & 2 & 1 & 4 & - & - \\
\hline Ev. teratodes & - & 2 & - & - & - & 4 & - & - & - & 1 & - & - & - & - & - & 1 & - & - \\
\hline Ev. termitophila & & & - & 1 & - & 1 & - & - & - & - & - & - & - & - & - & 2 & - & - \\
\hline Ex.firmatoi & 11 & 2 & 1 & - & 1 & - & - & - & - & - & - & - & - & - & - & - & - & - \\
\hline Mi. longipenis & 1 & - & - & 1 & - & - & 8 & 1 & - & 1 & - & - & - & - & - & 1 & - & - \\
\hline Mi. quinquefer & - & - & - & - & - & - & - & 1 & - & - & - & - & - & 7 & 1 & 5 & - & 1 \\
\hline Mg. migonei & 9 & 17 & 6 & 1 & - & 2 & 1 & - & - & - & 1 & - & 1 & - & - & - & - & - \\
\hline Ny.neivai & 328 & 344 & 12 & 20 & 21 & 44 & 1 & - & - & 1 & - & - & - & - & - & - & - & - \\
\hline Ny. withmani & 9 & 9 & 3 & 12 & - & 5 & - & - & - & 1 & - & - & 2 & 1 & 1 & 1 & 1 & - \\
\hline Pi. christenseni & - & 6 & - & 29 & - & 14 & - & 13 & - & 5 & - & - & - & 3 & - & 12 & - & - \\
\hline Pi monticola & - & - & - & 1 & - & - & 8 & 3 & - & 2 & - & - & - & - & - & - & - & - \\
\hline Pi.pessoai & 12 & 2 & 87 & 66 & 3 & 10 & 11 & 4 & 20 & 6 & 6 & 11 & 20 & 8 & 22 & 26 & - & 5 \\
\hline Pi. fischeri & - & - & - & 4 & 2 & 1 & - & - & - & - & - & - & - & - & 2 & 1 & - & - \\
\hline Psa. aragaoi & - & 11 & - & - & 1 & - & - & - & - & - & - & - & - & 1 & 1 & 2 & - & 1 \\
\hline Psa. campograndensis & - & 1 & - & - & - & - & - & - & - & 2 & - & - & - & 1 & - & - & - & - \\
\hline Psa. lanei & 21 & 17 & - & - & - & - & - & - & - & - & - & - & - & 1 & - & - & - & - \\
\hline Psa. shannoni & 3 & 4 & 8 & 4 & - & - & 2 & - & - & 1 & - & - & - & 1 & 5 & 3 & - & - \\
\hline Sci.sordelli & 2 & 9 & - & 3 & - & - & - & - & - & 2 & - & 1 & - & 5 & 2 & 2 & - & 1 \\
\hline
\end{tabular}

PER - Perobeiras (Parque Estadual Morro do Diabo); EC - Estreito de Cima (Parque Estadual Morro do Diabo); EB - Estreito de Baixo (Parque Estadual Morro do Diabo); PB -Fragmento Ponte Branca; TC - Fragmento Tucano; AS - Fragmento Água Sumida; RB - Fragmento Ribeirão Bonito; ROS - Fragmento Rosanela; COP - Fragmento Copacabana 
Tabela 3 - Distribuição do número de indivíduos capturados, segundo sexo, local e ponto de captura no Município de Teodoro Sampaio, SP - 2009

\begin{tabular}{|c|c|c|c|c|c|c|c|c|c|c|}
\hline \multirow{2}{*}{\multicolumn{2}{|c|}{ LOCAL }} & \multirow{2}{*}{\multicolumn{2}{|c|}{ Borda }} & \multirow{2}{*}{\multicolumn{2}{|c|}{100 metros }} & \multirow{2}{*}{\multicolumn{2}{|c|}{300 metros }} & \multirow{2}{*}{\multicolumn{2}{|c|}{500 metros }} & \multirow[t]{3}{*}{ Total } \\
\hline & & & & & & & & & & \\
\hline & & $\mathrm{s}$ & $\mathrm{s}$ & $\mathrm{s}$ & $\mathrm{s}$ & $\mathrm{s}$ & $\mathrm{s}$ & $\mathrm{s}$ & $\mathrm{s}$ & \\
\hline \multirow[t]{3}{*}{ PARQUE } & $\begin{array}{l}\text { PEMD } \\
\text { Perobeira }\end{array}$ & 371 & 353 & 1 & 18 & 11 & 11 & 23 & 58 & \multirow[t]{3}{*}{846} \\
\hline & $\begin{array}{l}\text { PEMD } \\
\text { Estreito } \\
\text { de Cima }\end{array}$ & 122 & 120 & - & 10 & 16 & 27 & 1 & 4 & \\
\hline & $\begin{array}{l}\text { PEMD } \\
\text { Estreito } \\
\text { de Baixo }\end{array}$ & 23 & 53 & 1 & 17 & 1 & 19 & 20 & 21 & \\
\hline \multirow[t]{8}{*}{ FRAGMENTOS } & $\begin{array}{l}\text { Ponte } \\
\text { Branca }\end{array}$ & 15 & 17 & 22 & 9 & 39 & 22 & - & - & \multirow{3}{*}{$\begin{array}{c}124 \\
50\end{array}$} \\
\hline & Tucano & 1 & 5 & 0 & 10 & 0 & 3 & 21 & 10 & \\
\hline & Água & 0 & 3 & 5 & 7 & 8 & 8 & - & - & \\
\hline & Sumida & & & & & & & & & \multirow{2}{*}{$\begin{array}{c}31 \\
234\end{array}$} \\
\hline & Rosanela & 117 & 86 & 3 & 4 & 3 & 11 & - & 10 & \\
\hline & Ribeirão & 24 & 15 & 1 & 4 & 15 & 12 & 31 & 50 & \multirow{3}{*}{152} \\
\hline & Bonito & & & & & & & & & \\
\hline & $\begin{array}{l}\text { Copacaba } \\
\text { na }\end{array}$ & 14 & 36 & - & - & 7 & 4 & - & 7 & \\
\hline \multicolumn{2}{|l|}{ Total } & 687 & 688 & 33 & 79 & 100 & 117 & 96 & 160 & 1960 \\
\hline
\end{tabular}

Os resultados dos cálculos do IAEP (Índice de Abundância de Espécies Padronizado) estão ilustrados na figura 3 e 4 e demonstram predominância do gênero Brumptomyia sp em quase todos os pontos de captura, com exceção daqueles instalados na borda do Parque Estadual Morro do Diabo, que apresentaram Nyssomyia neivai como espécie dominante. A abundância de Nyssomyia neivai nos fragmentos foi muito baixa se comparado ao Parque, onde foram capturados apenas dois espécimes nos fragmentos Tucano e Ponte Branca.

No Parque, segundo os resultados do IAEP, considerando todos os pontos de captura, as principais espécies foram Brumptomyia sp (0,95), Pintomyia christenseni $(0,79)$, Migonemyia migonei $(0,76)$ e Pintomyia pessoai $(0,73)$. Analisando apenas os pontos da borda da mata, Nyssomyia neivai foi a predominante $(0,97)$, seguida por Nyssomyia withmani e Pintomyia pessoai $(0,86)$, Brumptomyia sp $(0,72)$ e Migonemyia migonei $(0,67)$.

Nos fragmentos considerados médios, o ranking do IAEP foi Brumptomyia sp $(0,91)$, Pintomyia pessoai $(0,87)$, Pintomyia christenseni $(0,72)$, Micropigomyia longipenis $(0,53)$ e Pintomyia monticola $(0,41)$. Considerando apenas a borda temos a dominância de Brumptomyia sp. (1,00), seguida de Pintomyia pessoai $(0,48)$, Pintomyia christenseni $(0,27)$ e Pintomyia monticola $(0,27)$.

Nos fragmentos pequenos, observou-se a dominância de Brumptomyia sp. (1,00), seguida de Pintomyia christenseni $(0,69)$, Sciopemyia sordelli $(0,64)$ e Micropigomyia 
quinquefer $(0,63)$. Considerando apenas a borda, Brumptomyia sp.(0,97) e Pintomyia pessoai $(0,93)$ foram as mais abundantes e apresentaram valores semelhantes, seguidas por Nyssomyia withmani $(0,53)$, Evandromyia lenti $(0,48)$ e Sciopemyia sordelli $(0,64)$.

Índice de Abundância de Espécies (IAEP)

Parque

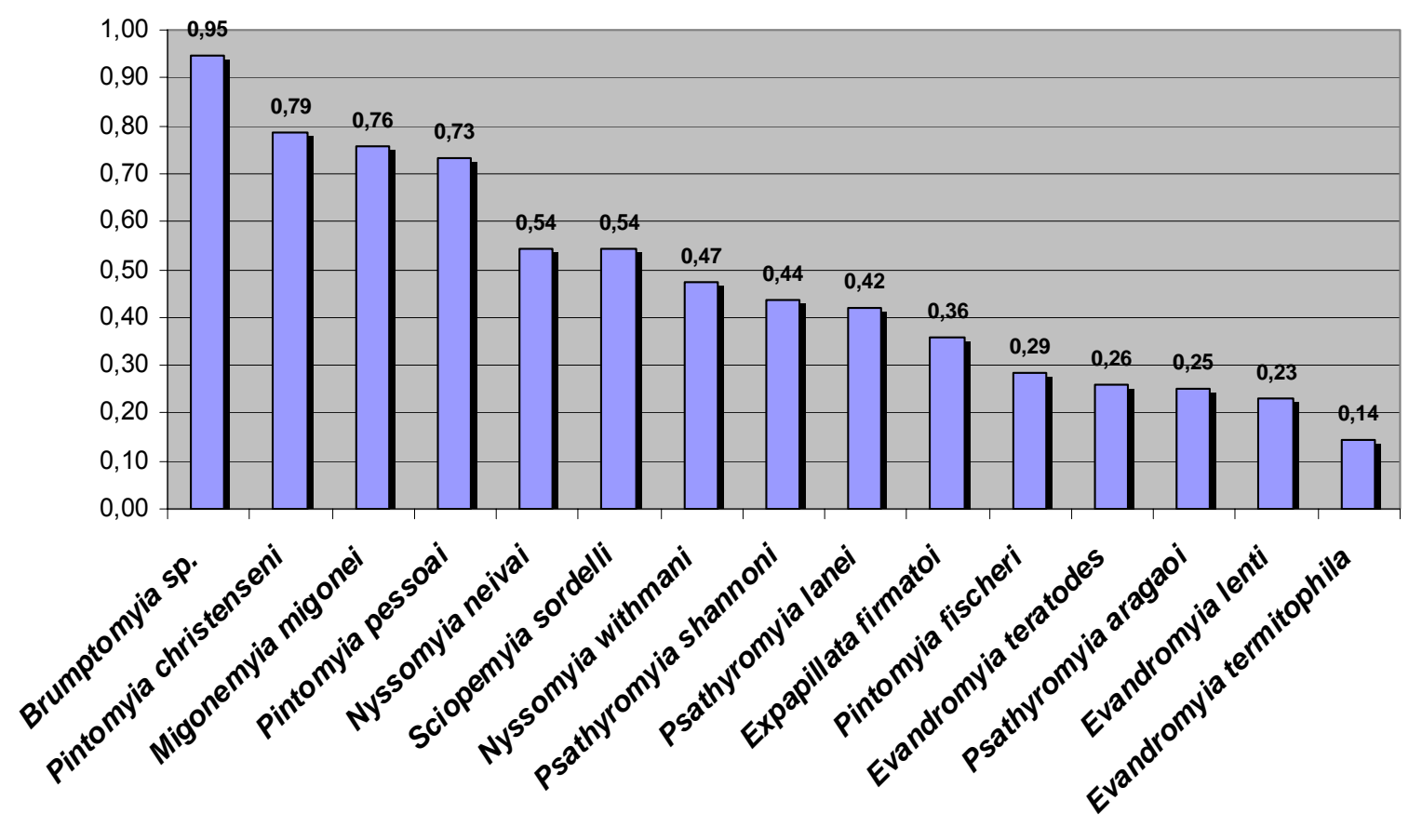

Índice de Abundância de Espécies (IAEP)

Fragmentos Pequenos
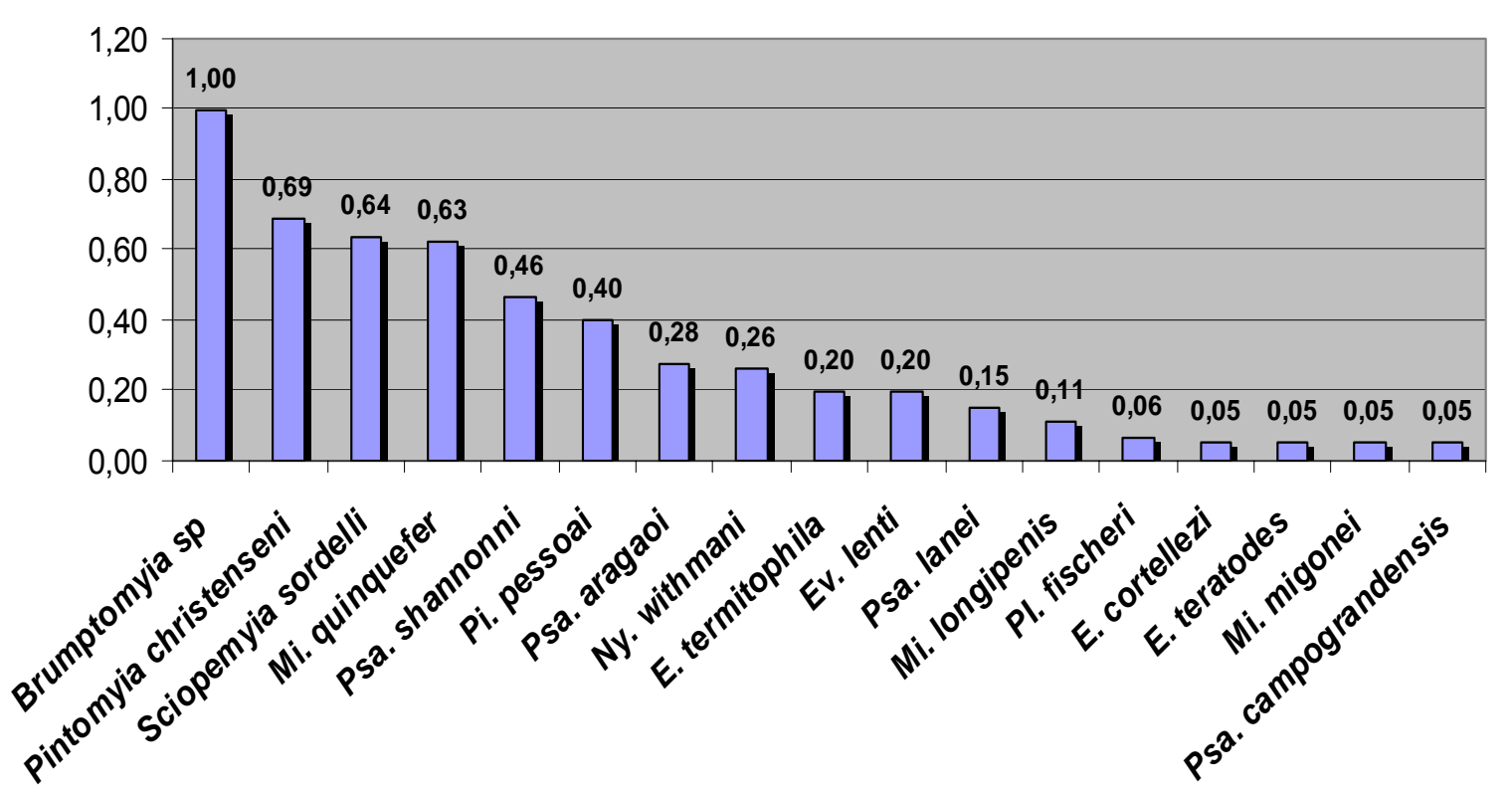
Índice de Abundância de Espécies

Fragmentos Médios

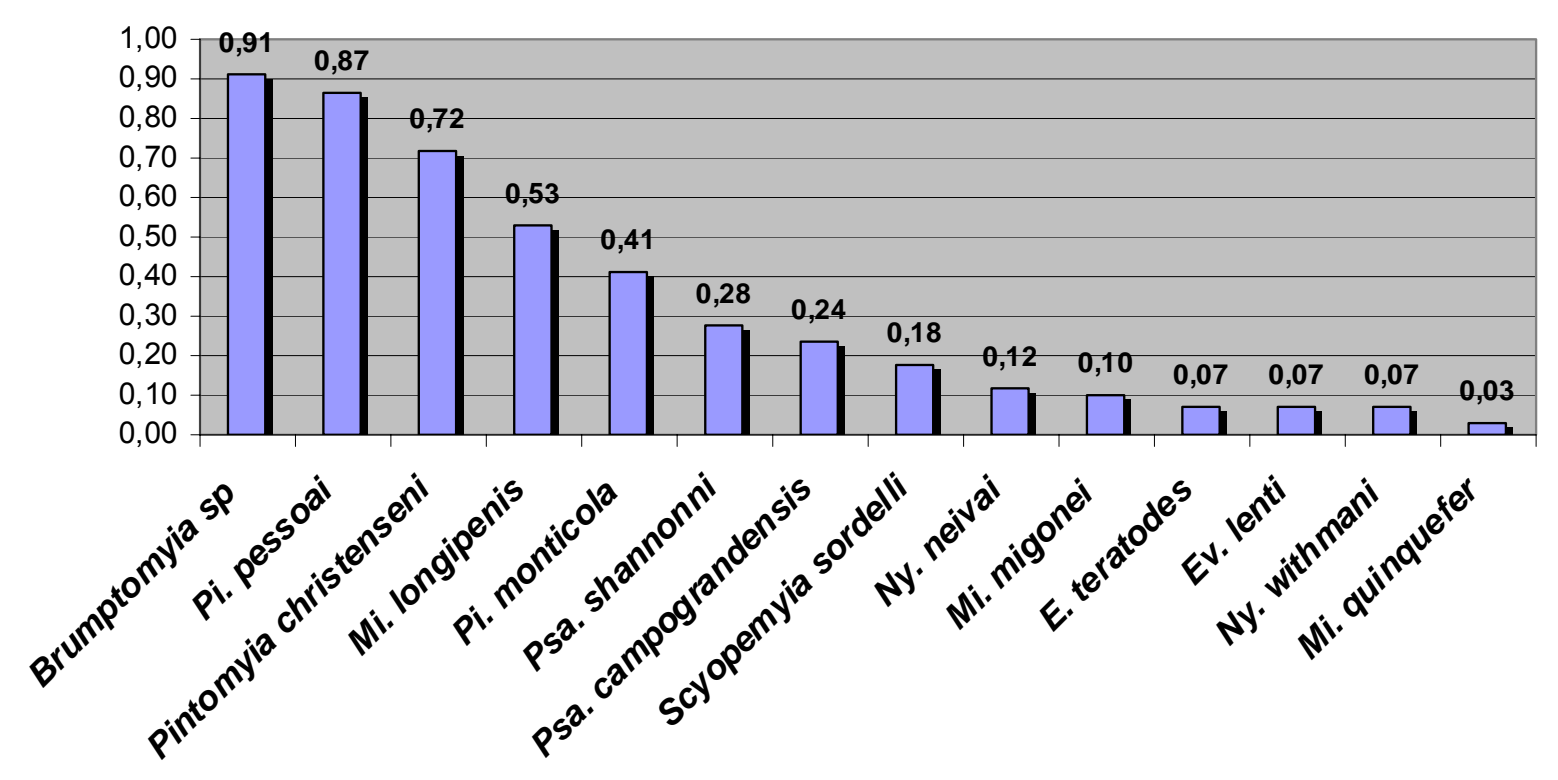

Figura 3 - Índice de Abundância de Espécies Padronizado (IAEP) de flebotomíneos nos fragmentos categorizados por tamanho e no Parque Estadual Morro do Diabo. Teodoro Sampaio 2008-2009

\section{Índice de Abundância de Espécies Borda Parque}

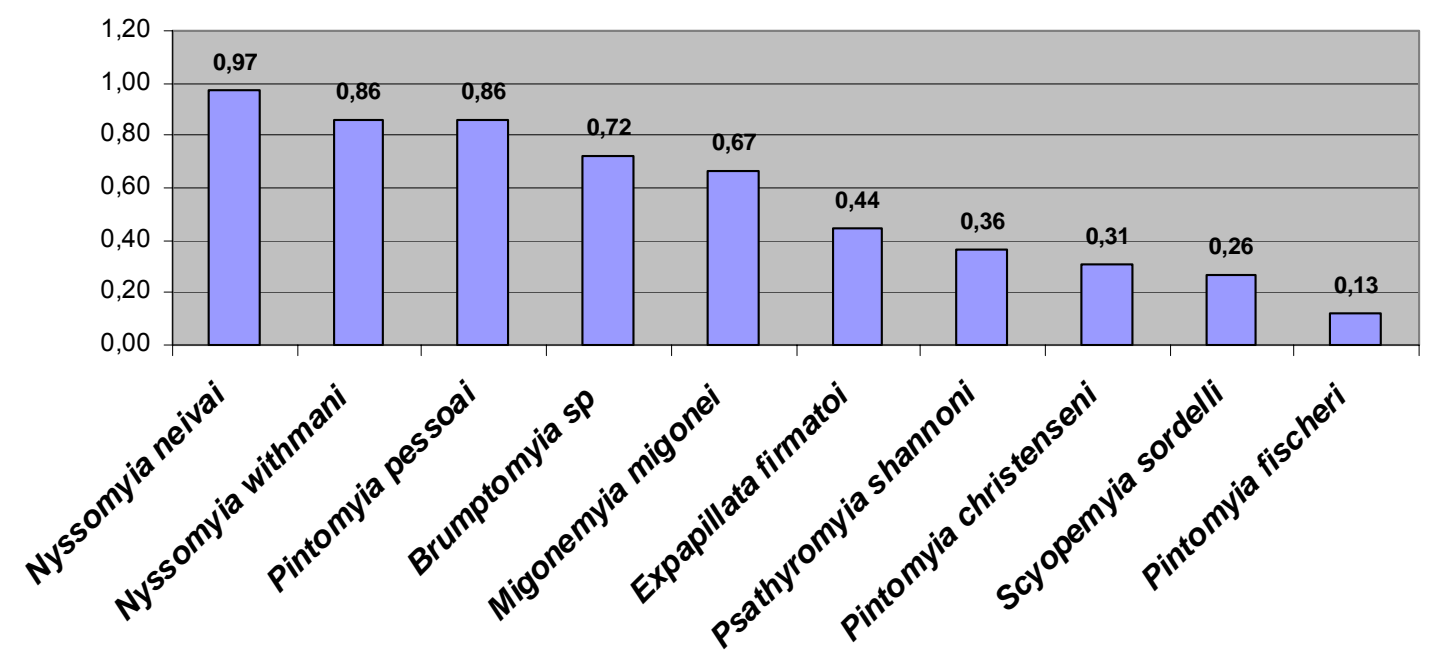


Índice de Abundância de Espécies Borda

Fragmentos Médios

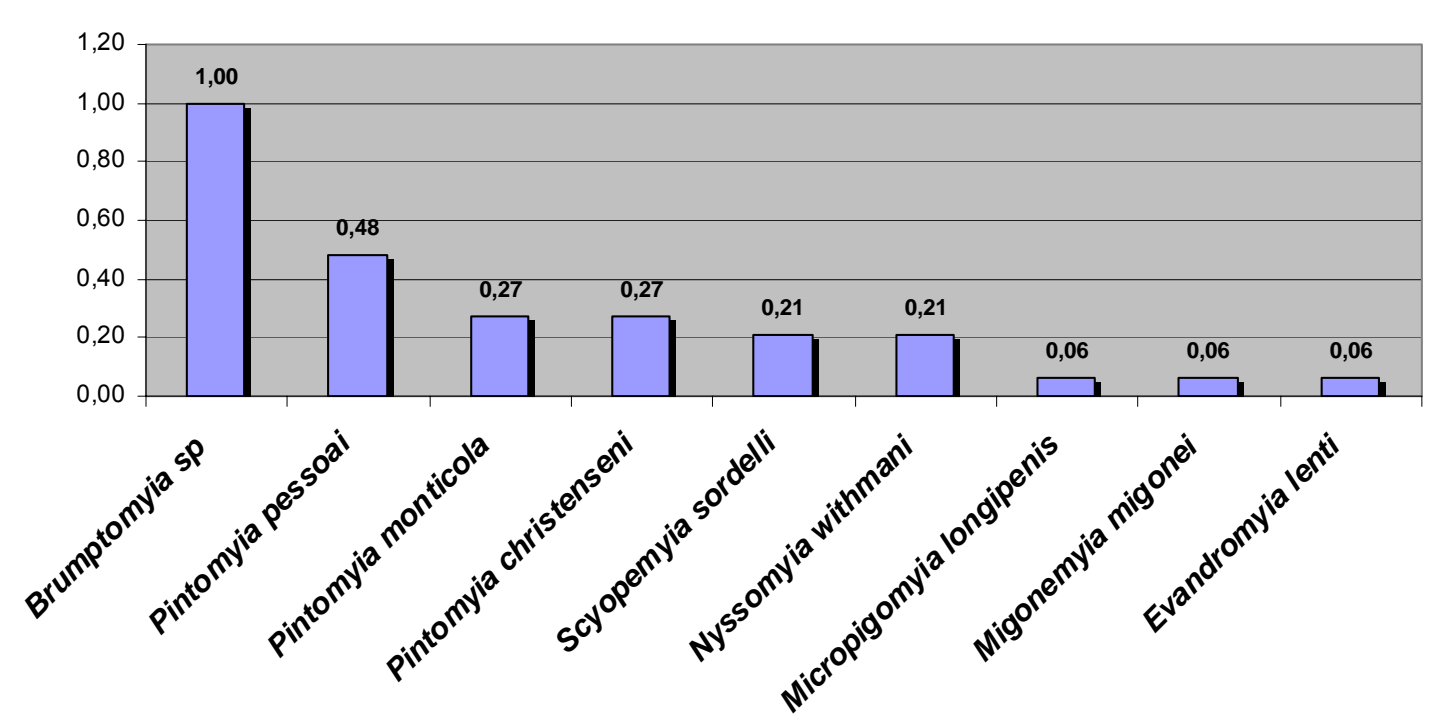

Índice de Abundância de Espécies Borda

Fragmentos Pequenos

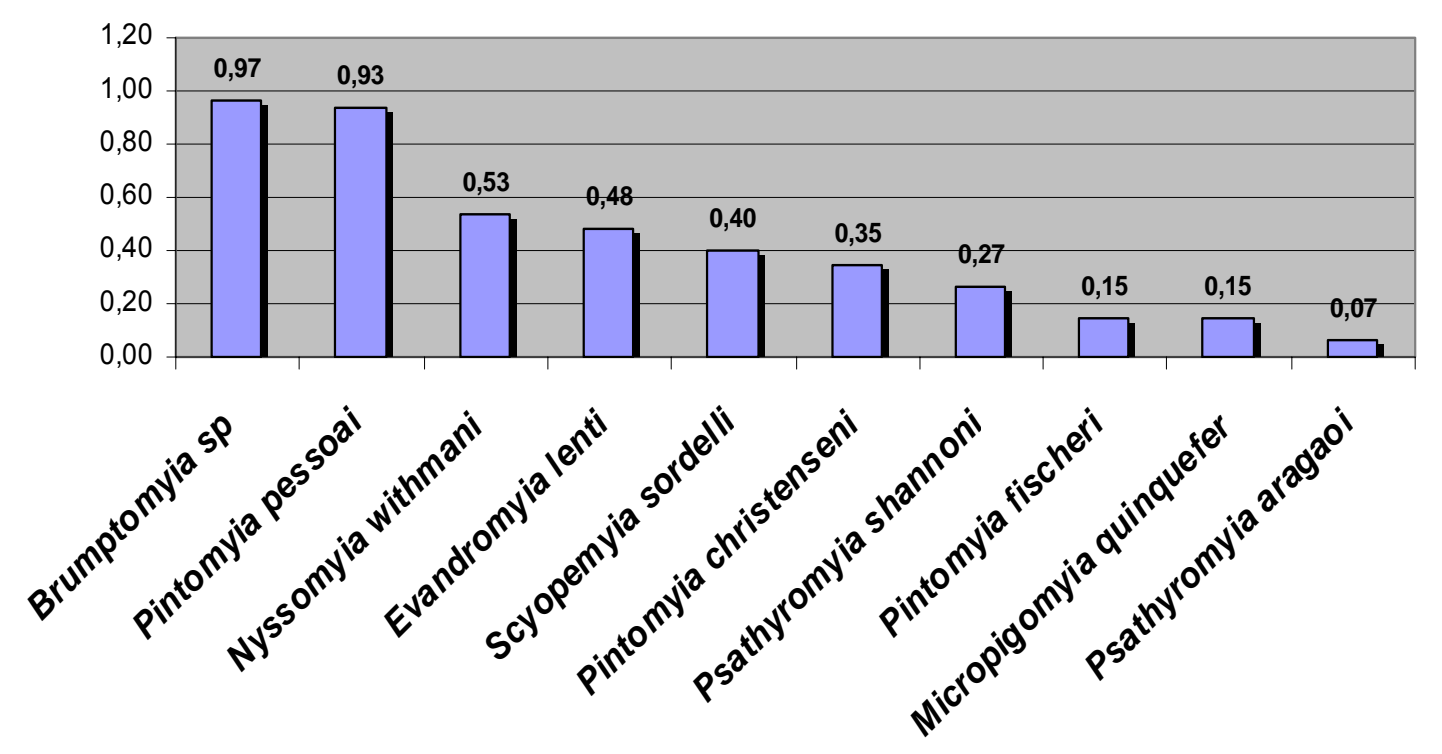

Figura 4 - Índice de Abundância de Espécies Padronizado (IAEP) de flebotomíneos capturados na borda dos Fragmentos e Parque Estadual Morro do Diabo - Teodoro Sampaio - 20082009

Os índices de riqueza, diversidade e equitabilidade estão demonstrados na tabela 4. As áreas amostrais foram demonstradas isoladamente e agrupadas pela categoria de tamanho (pequeno, médio e grande). Os maiores índices de riqueza e diversidade foram encontrados no 
Parque Estadual Morro do Diabo. Dentre os fragmentos, os maiores foram no Tucano, Ribeirão Bonito e Rosanela e os menores no Água Sumida.

Tucano e Água Sumida foram aqueles que apresentaram os maiores índices de equitabilidade. Contudo, foram aqueles com menor número de indivíduos capturados. A tabela 5 mostra os mesmos índices com as áreas amostrais agrupadas pela categoria de tamanho.

Tabela 4 - Índices calculados para cada uma das áreas amostrais

\begin{tabular}{|c|c|c|c|c|c|}
\hline Local & $\begin{array}{c}\mathrm{N}^{\circ} \text { de } \\
\text { Espécies }\end{array}$ & $\begin{array}{c}\text { Riqueza } \\
\text { Margalef }\end{array}$ & $\begin{array}{c}\text { Índice de } \\
\text { Shannon } \\
(\mathbf{H})\end{array}$ & $\begin{array}{c}\text { Equitabilidade } \\
\text { de Pielou (J) }\end{array}$ & $\begin{array}{c}\text { Equitabilidade } \\
\text { Busas (E) }\end{array}$ \\
\hline Perobeiras & 15 & 2,08 & 0,80 & 0,29 & 0,15 \\
\hline Estreito de & & & 1,31 & 0,46 & 0,22 \\
\hline Cima & 17 & 2,81 & & & \\
\hline Estreito de & & & 1,69 & 0,68 & 0,45 \\
\hline Baixo & 12 & 2,18 & & & \\
\hline Tucano & 11 & 2,56 & 1,64 & 0,68 & 0,47 \\
\hline Ponte & & & 1,44 & 0,63 & 0,42 \\
\hline Branca & 10 & 1,87 & & & \\
\hline Água & & & 0,92 & 0,66 & 0,63 \\
\hline Sumida & 4 & 0,87 & & & \\
\hline Ribeirão & & & 1,29 & 0,50 & 0,28 \\
\hline Bonito & 13 & 2,39 & & & \\
\hline Rosanela & 13 & 2,20 & 1,39 & 0,54 & 0,31 \\
\hline Copacabana & 6 & 1,18 & 0,56 & 0,31 & 0,29 \\
\hline
\end{tabular}

Tabela 5 - Índices calculados das áreas amostrais agrupadas por tamanho

\begin{tabular}{cccccc}
\hline Local & $\begin{array}{c}\mathbf{N}^{\circ} \text { de } \\
\text { Espécies }\end{array}$ & $\begin{array}{c}\text { Riqueza } \\
\text { Margalef }\end{array}$ & $\begin{array}{c}\text { Índice de } \\
\text { Shannon } \\
\mathbf{( H )}\end{array}$ & $\begin{array}{c}\text { Equitabilidade } \\
\text { de Pielou (J) }\end{array}$ & $\begin{array}{c}\text { Equitabilidade } \\
\text { Busas (E) }\end{array}$ \\
\hline PEMD & 20 & 2,68 & 1,38 & 0,46 & 0,20 \\
Médio & 14 & 2,44 & 1,62 & 0,61 & 0,36 \\
Pequeno & 17 & 2,62 & 1,29 & 0,45 & 0,21 \\
\hline
\end{tabular}

PEMD (Estreito de Cima, Estreito de Baixo e Perobeira), Médio (Tucano, Água Sumida e Ponte Branca), Pequeno (Ribeirão Bonito, Rosanela e Copacabana) 


\subsection{CAPTURA DOS MAMÍFEROS}

Foram realizadas 317 capturas de mamíferos, sendo 255 indivíduos dentre sete espécies, com um total de 5944 armadilhas x noite, obtendo um sucesso de captura total de 5,8\%. O marsupial Didelphis albiventris representou 72,56\% (230) do total de capturas, seguida pelo roedor Akodon cursor com 16,72\% (53), Dasyprocta azarae e Micoureus paraguayanus com 3,15\% (10), Metachirus nudicaudatus com 2,52\% (8) e Hylaeamys megacephalus e Necromys lasiurus com 0,63\% (2) (Figura 5).
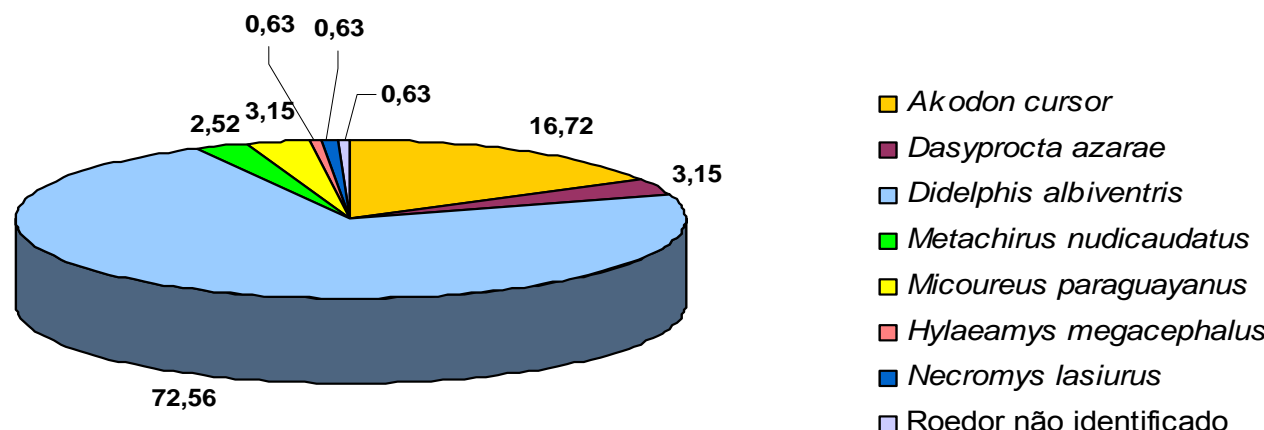

Figura 5 - Proporção de espécies de mamíferos capturados do total de capturas

Didelphis albiventris foi o único encontrado em todas as áreas de amostragem. O número de indivíduos capturados, excluindo as recapturas, foi 172 Didelphis albiventris, 50 Akodon cursor, 8 Metachirus nudicaudatus, 10 Dasyprocta azarae, 8 Micoureus paraguayanus, 2 Necromys lasiurus, 2 Hylaeamys megacephalus e 2 roedores não identificados. A tabela 6 mostra em detalhes o número total de indivíduos capturados, de cada espécie e em cada local. 
Tabela 6 - Espécies, local e número de capturas dos mamíferos em fragmentos florestais do Município de Teodoro Sampaio (SP) - 2008-9

\begin{tabular}{|c|c|c|c|c|c|c|c|c|c|c|}
\hline Espécies & PER & EC & EB & PB & $\begin{array}{c}\text { Local } \\
\text { TC }\end{array}$ & AS & RB & ROS & COP & Total \\
\hline $\begin{array}{l}\text { Akodon } \\
\text { cursor }\end{array}$ & - & 30 & 0 & 1 & 5 & 3 & 2 & 1 & 9 & 51 \\
\hline $\begin{array}{l}\text { Dasyprocta } \\
\text { azarae }\end{array}$ & 1 & 0 & 5 & 1 & 1 & 1 & 0 & 0 & 1 & 10 \\
\hline $\begin{array}{l}\text { Didelphis } \\
\text { albiventris }\end{array}$ & 11 & 25 & 4 & 21 & 38 & 8 & 17 & 22 & 26 & 172 \\
\hline $\begin{array}{l}\text { Metachirus } \\
\text { nudicaudatus }\end{array}$ & 2 & 2 & 2 & 0 & 0 & 0 & 2 & 0 & 0 & 8 \\
\hline $\begin{array}{l}\text { Micoureus } \\
\text { paraguayanus }\end{array}$ & 1 & 2 & 1 & 0 & 0 & 1 & 1 & 2 & 0 & 8 \\
\hline $\begin{array}{l}\text { Hylaeamys } \\
\text { megacephalus }\end{array}$ & - & 2 & 0 & 0 & 0 & 0 & 0 & 0 & 0 & 2 \\
\hline $\begin{array}{l}\text { Necromys } \\
\text { lasiurus }\end{array}$ & - & 0 & 0 & 0 & 0 & 0 & 0 & 0 & 2 & 2 \\
\hline $\begin{array}{l}\text { Roedor não } \\
\text { identificado }\end{array}$ & - & 0 & 0 & 0 & 2 & 0 & 0 & 0 & 0 & 2 \\
\hline Total & 15 & 61 & 12 & 23 & 46 & 13 & 22 & 25 & 38 & 255 \\
\hline
\end{tabular}

Além dos animais relacionados acima, foram amostrados alguns indivíduos fora das áreas selecionadas dentro do desenho amostral do projeto. Estes dados não foram inseridos nas análises de riqueza e abundância, no entanto, o material obtido desses indivíduos também foi analisado para a pesquisa de Leishmania spp. Esta área consistia em um fragmento da região e corredores agroflorestais, vizinhos das áreas de estudo, onde, no total, foram capturados 13 Akodon cursor, 21 Didelphis albiventris, 1 Micoureus paraguayanus, 1 Metachirus nudicaudatus, 4 Oligorizomys sp.

Os resultados dos índices calculados para as espécies de mamíferos estão demonstrados na tabela 7. A área amostrada no Parque Estadual Morro do Diabo, Estreito de Baixo, apresentou os maiores índices de riqueza, diversidade e equitabilidade. Dentre os fragmentos, Água Sumida foi aquele com maiores índices. Se as áreas forem agrupadas pela categoria de tamanho, o PEMD segue com os maiores índices de diversidade e equitabilidade. 
No entanto, os fragmentos pequenos foram ligeiramente superiores no índice de riqueza (Tabela 8).

Tabela 7 - Índices calculados para as espécies de mamíferos capturados em cada uma das áreas amostrais - Teodoro Sampaio - 2008-2009

\begin{tabular}{|c|c|c|c|c|c|}
\hline Local & $\begin{array}{c}\mathbf{N}^{\circ} \text { de } \\
\text { Espécies }\end{array}$ & $\begin{array}{l}\text { Riqueza } \\
\text { Margalef }\end{array}$ & $\begin{array}{c}\text { Índice de } \\
\text { Shannon } \\
(\mathbf{H})\end{array}$ & $\begin{array}{c}\text { Equitabilidade } \\
\text { de Pielou (J) }\end{array}$ & $\begin{array}{c}\text { Equitabilidade } \\
\text { Busas (E) }\end{array}$ \\
\hline Perobeiras & 4 & 1,11 & 0,86 & 0,32 & 0,16 \\
\hline Estreito de & & & & & \\
\hline Cima & 5 & 0,97 & 1,05 & 0,26 & 0,05 \\
\hline Estreito de & & & & & \\
\hline Baixo & 4 & 1,21 & 1,24 & 0,50 & 0,29 \\
\hline $\begin{array}{l}\text { Tucano } \\
\text { Ponte }\end{array}$ & 3 & 0,64 & 0,36 & 0,11 & 0,06 \\
\hline $\begin{array}{l}\text { Branca } \\
\text { Água }\end{array}$ & 4 & 0,78 & 0,62 & 0,16 & 0,04 \\
\hline $\begin{array}{l}\text { Sumida } \\
\text { Ribeirão }\end{array}$ & 4 & 1,17 & 1,03 & 0,40 & 0,22 \\
\hline Bonito & 4 & 0,97 & 0,78 & 0,25 & 0,10 \\
\hline Rosanela & 3 & 0,62 & 0,44 & 0,14 & 0,06 \\
\hline Copacabana & 4 & 0,82 & 0,83 & 0,23 & 0,06 \\
\hline
\end{tabular}

Tabela 8 - Índices calculados para as espécies de mamíferos capturados nas amostrais categorizadas por tamanho - Teodoro Sampaio - 2008-2009

\begin{tabular}{|c|c|c|c|c|c|}
\hline Local & $\begin{array}{c}\mathrm{N}^{\circ} \text { de } \\
\text { Espécies }\end{array}$ & $\begin{array}{c}\text { Riqueza } \\
\text { Margalef }\end{array}$ & $\begin{array}{c}\text { Índice de } \\
\text { Shannon } \\
(\mathbf{H}) \\
\end{array}$ & $\begin{array}{l}\text { Equitabilidade } \\
\text { de Pielou (J) }\end{array}$ & $\begin{array}{c}\text { Equitabilidade } \\
\text { Busas (E) }\end{array}$ \\
\hline PEMD & 6 & 1,12 & 1,32 & 0,29 & 0,04 \\
\hline Médio & 5 & 0,91 & 0,67 & 0,15 & 0,02 \\
\hline Pequeno & 6 & 1,13 & 0,83 & 0,19 & 0,03 \\
\hline
\end{tabular}

PEMD (Estreito de Cima, Estreito de Baixo e Perobeira), Médio (Tucano, Água Sumida e Ponte Branca), Pequeno (Ribeirão Bonito, Rosanela e Copacabana)

O total de amostras obtidas, por espécie, está relacionado na tabela 9. Ao todo, foram colhidas e analisadas 198 amostras de pele e 181 amostras de sangue. Deste montante, em 140 indivíduos foi possível a obtenção de ambas as amostras. Em alguns casos, houve insucesso na coleta do sangue e optou-se apenas pela coleta da pele. Fatores ambientais como chuva e frio também foram limitantes para a obtenção de um maior número de amostras, tendo em vista que muitas vezes o animal se encontrava hipotérmico, sem condições de ser submetido ao procedimento normal. Nestes casos, os indivíduos recebiam a marcação e eram liberados. Do total de amostras de pele (198), oito foram oriundas de indivíduos recapturados, sendo 
sete Didelphis albiventris e um Metachirus nudicaudatus. Das amostras totais de sangue (181), nove amostras foram obtidas de recapturas, de indivíduos da espécie Didelphis albiventris. $\mathrm{O}$ total de indivíduos amostrados, segundo tipo de amostra está descrito na tabela 10.

Tabela 9 - Total de amostras por espécie de mamífero capturado nos fragmentos florestais do Município de Teodoro Sampaio (SP) - 2008-2009

\begin{tabular}{lcc}
\hline Espécie & Pele & Sangue total \\
\hline Didelphis albiventris & 127 & 128 \\
Akodon cursor & 39 & 31 \\
Metachirus nudicaudatus & 9 & 5 \\
Dasyprocta azarae & 9 & 9 \\
Micoureus paraguayanus & 7 & 3 \\
Necromys lasiurus & 2 & 2 \\
Hylaeamys megacephalus & 2 & 2 \\
Roedores não identificados & 2 & 1 \\
Oligorizomys sp & 1 & 1 \\
\hline Total & 198 & 181 \\
\hline
\end{tabular}

Tabela 10 - Amostra clínica obtida e número de indivíduos submetidos à pesquisa de Leishmania sp em cada tipo de amostra

\begin{tabular}{lc}
\hline \multicolumn{1}{c}{ Tipo de Amostra } & Número de Indivíduos Amostrados \\
\hline Pele e Sangue & 140 \\
Pele & 58 \\
Sangue & 41 \\
\hline Total & 239 \\
\hline
\end{tabular}

\subsection{PESQUISA DE LEISHMANIA SP NOS FLEBÓTOMOS}

Foram realizadas a PCR de 872 indivíduos dentre noventa pools, sendo que todos apresentaram resultados negativos (Figura 6). O número e as espécies de flebótomos dos pools formados para extração do DNA, que foram submetidos à PCR, estão demonstrados na tabela 11. 
Tabela 11 - Pools de flebotomíneos capturados no município de Teodoro Sampaio durante o período de ago/2008 e maio/2009, agrupados por espécie, local de captura e número de indivíduos preparados para extração do DNA

\begin{tabular}{|c|c|c|c|}
\hline Espécie & Local & $\begin{array}{l}\text { Número de } \\
\text { Pools }\end{array}$ & $\begin{array}{c}\text { Total de } \\
\text { Indivíduos }\end{array}$ \\
\hline Brumptomyia sp. & Água Sumida & 1 & 5 \\
\hline Pi. Pessoai & Água Sumida & 1 & 9 \\
\hline Pi. christenseni & Água Sumida & 1 & 1 \\
\hline Scy. Sordelli & Água Sumida & 1 & 1 \\
\hline Brumptomyia sp. & Copacabana & 2 & 39 \\
\hline Pi. Pessoai & Copacabana & 1 & 5 \\
\hline Psa. aragaoi & Copacabana & 1 & 1 \\
\hline Mi. quinquefer & Copacabana & 1 & 1 \\
\hline Scy. sordelli & Copacabana & 1 & 1 \\
\hline Brumptomyia sp. & Ponte Branca & 1 & 5 \\
\hline Mi. Quinquefer & Ponte Branca & 1 & 1 \\
\hline Pi. christenseni & Ponte Branca & 1 & 19 \\
\hline Pi. Monticola & Ponte Branca & 1 & 5 \\
\hline Pi. pessoai & Ponte Branca & 1 & 11 \\
\hline Brumptomyia sp. & Ribeirão Bonito & 3 & 49 \\
\hline Ev. cortellezi & Ribeirão Bonito & 1 & 1 \\
\hline Ev.lenti & Ribeirão Bonito & 1 & 2 \\
\hline Mi. quinquefer & Ribeirão Bonito & 1 & 7 \\
\hline Ny. withmani & Ribeirão Bonito & 1 & 1 \\
\hline Pi. christenseni & Ribeirão Bonito & 1 & 3 \\
\hline Pi. pessoai & Ribeirão Bonito & 1 & 8 \\
\hline Psa. aragaoi & Ribeirão Bonito & 1 & 1 \\
\hline Psa.campograndensis & Ribeirão Bonito & 1 & 1 \\
\hline Psa. lanei & Ribeirão Bonito & 1 & 1 \\
\hline Psa. shannoni & Ribeirão Bonito & 1 & 4 \\
\hline Scy. sordelli & Ribeirão Bonito & 1 & 5 \\
\hline Brumptomyia sp. & Rosanela & 3 & 51 \\
\hline Ev. lenti & Rosanela & 1 & 4 \\
\hline Ev. teratodes & Rosanela & 1 & 2 \\
\hline Ev. termitophila & Rosanela & 1 & 1 \\
\hline Mi. quinquefer & Rosanela & 1 & 5 \\
\hline Ny. withmani & Rosanela & 1 & 1 \\
\hline Pi. christenseni & Rosanela & 1 & 12 \\
\hline PI. fischeri & Rosanela & 1 & 1 \\
\hline Pi. pessoai & Rosanela & 2 & 26 \\
\hline Psa. aragaoi & Rosanela & 1 & 2 \\
\hline Psa. shannoni & Rosanela & 1 & 3 \\
\hline Scy. sordelli & Rosanela & 1 & 2 \\
\hline Ev. teratodes & Tucano & 1 & 1 \\
\hline Mi. longipenis & Tucano & 1 & 1 \\
\hline Ny. neivai & Tucano & 1 & 1 \\
\hline Ny. withmani & Tucano & 1 & 1 \\
\hline Pi. monticola & Tucano & 1 & 2 \\
\hline Psa.campograndensis & Tucano & 1 & 1 \\
\hline Scy. sordelli & Tucano & 1 & 2 \\
\hline Brumptomyia sp. & PEMD & 3 & 56 \\
\hline Bi. flaviscutellata & PEMD & 1 & 1 \\
\hline Ev. carmelinoi & PEMD & 1 & 1 \\
\hline Ev. cortellezi & PEMD & 1 & 1 \\
\hline Ev. lenti & PEMD & 1 & 3 \\
\hline Ev. teratodes & PEMD & 1 & 3 \\
\hline Ev. termitophila & PEMD & 1 & 2 \\
\hline Mi. longipenis & PEMD & 1 & 1 \\
\hline Mi. migonei & PEMD & 1 & 20 \\
\hline Ny. neivai & PEMD & 16 & 311 \\
\hline Ny. withmani & PEMD & 2 & 21 \\
\hline Pi. christenseni & PEMD & 3 & 44 \\
\hline Pi. fischeri & PEMD & 1 & 5 \\
\hline
\end{tabular}




\begin{tabular}{cccc} 
Espécie & Local & $\begin{array}{c}\text { Número de } \\
\text { Pools }\end{array}$ & $\begin{array}{c}\text { (Conclusão) } \\
\text { Total de } \\
\text { Indivíduos }\end{array}$ \\
Pi. monticola & PEMD & 1 & 1 \\
Pi. pessoai & PEMD & 4 & 74 \\
Psa.campograndensis & PEMD & 1 & 1 \\
Psa. lanei & PEMD & 1 & 17 \\
Psa. shannoni & PEMD & 1 & 1 \\
Scy. sordelli & PEMD & 1 & 3 \\
\hline
\end{tabular}

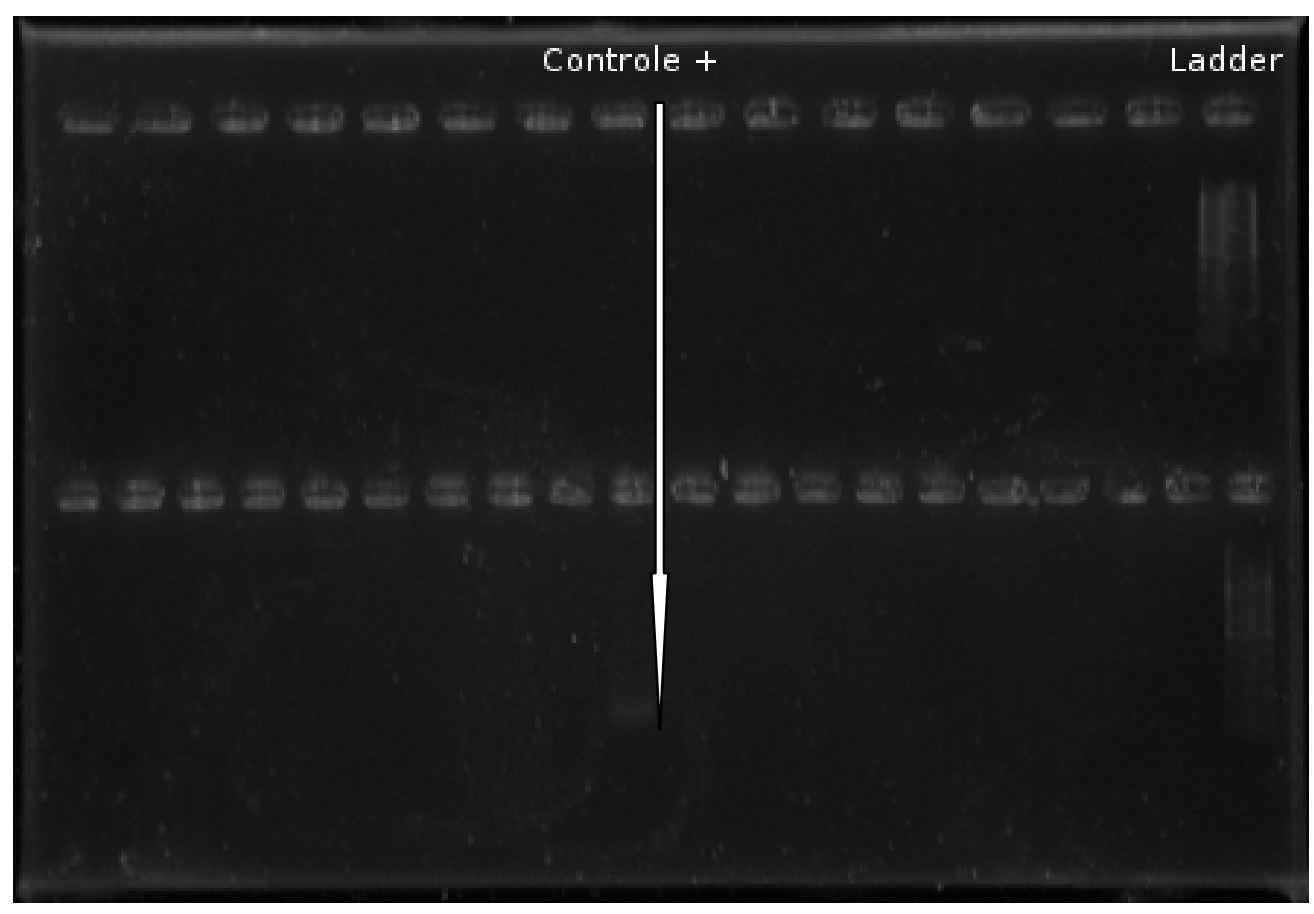

Figura 6 - Amostras de pools de flebotomíneos submetidas a PCR, apresentando resultado negativo. Visualização do controle positivo (120 pares de bases) e ladder, em gel de agarose 2\%

\subsection{PESQUISA DE LEISHMANIA SP NO TECIDO DOS MAMÍFEROS}

Do total de amostras colhidas e analisadas (239), oito apresentaram amplificação do fragmento de DNA correspondente ao produto da PCR utilizando o primer de Rodgers et al. (1990). A tabela 12 apresenta a distribuição do número de animais capturados e do número de positivos segundo espécie e área de captura categorizada por tamanho. A freqüência de animais positivos nos fragmentos de tamanho pequeno, médio e o Parque não apresentaram diferença significativa $\left(\chi^{2}=0.2844 ; \mathrm{gl}=2 ; \mathrm{p}=0.867\right)$. O total de indivíduos amostrados, e a frequência de animais positivos, por espécie, está relacionado na tabela 13. 
Dentre 198 amostras de pele, três apresentaram resultados positivos, oriundas de indivíduos da espécie Didelphis albiventris, capturados nos fragmentos Copacabana (2) e Água Sumida (1). Do total das amostras extraídas de sangue (181), dois indivíduos da espécie Akodon cursor (roedor silvestre), uma de Dasyprocta azarae (cutia), uma de Didephis albiventris e uma de Oligorizomys sp apresentaram resultados positivos. As espécies e locais de captura dos indivíduos positivos estão relacionados na tabela 14 .

Tabela 12 - Freqüência de Leishmania sp nos mamíferos amostrados nos locais de captura categorizados por tamanho - Teodoro Sampaio - 2008-2009

\begin{tabular}{cccc}
\hline Local & $\begin{array}{c}\mathbf{N}^{\circ} \text { de Animais } \\
\text { Amostrados }\end{array}$ & Positivos & Freqüência \% \\
\hline PEMD & 83 & 2 & $2,41[0,29 ; 8,43]$ \\
Fragmento Médio & 58 & 2 & $3,45[0,42 ; 11,91]$ \\
Fragmento Pequeno & 78 & 3 & $3,85[0,80 ; 10,83]$ \\
\hline Total & 219 & 7 & $3,20[1,29 ; 6,47]$ \\
\hline
\end{tabular}

Tabela 13 - Freqüência de Leishmania sp nos mamíferos amostrados por espécie - Teodoro Sampaio 2008-2009

\begin{tabular}{lccc}
\hline \multicolumn{1}{c}{ Espécie } & $\begin{array}{c}\mathbf{N}^{\circ} \mathbf{d e} \text { Animais } \\
\text { Amostrados }\end{array}$ & Positivos & Frequência \% \\
\hline Didelphis albiventris & 164 & 4 & $2,44[0,67 ; 6,13]$ \\
Akodon cursor & 42 & 2 & $4,76[0,58 ; 16,16]$ \\
Metachirus nudicaudatus & 9 & 0 & $0,00[0,00 ; 33,62]$ \\
Dasyprocta azarae & 9 & 1 & $11,11[0,28 ; 48,25]$ \\
Micoureus paraguayanus & 9 & 0 & $0,00[0,00 ; 33,62]$ \\
Necromys lasiurus & 2 & 0 & $0,00[0,00 ; 84,19]$ \\
Hylaeamys & 2 & 0 & $0,00[0,00 ; 84,19]$ \\
megacephalus & & 0 & $0,00[0,00 ; 97,5]$ \\
Roedores não & 1 & 1 & $100,00[2,5 ; 100,00]$ \\
identificados & & 8 & $2,44[0,67 ; 6,13]$ \\
Oligorizomys sp & 1 & & \\
\hline \multicolumn{1}{c}{ Total } & 239 & &
\end{tabular}

Tabela 14 - Espécie, tipo de amostra e local de captura dos indivíduos com amostra positiva para PCR de Leishmania sp, utilizando os primers de Rodgers et al. (1990) - Teodoro Sampaio - 2008-2009

\begin{tabular}{lll}
\hline Espécie & Amostra biológica & Fragmento de captura \\
\hline Didelphis albiventris & Pele & Copacabana \\
Didelphis albiventris & Pele & Copacabana \\
Didelphis albiventris & Pele & Água Sumida \\
Didelphis albiventris & Sangue & Estreito de Cima (PEMD) \\
Dasyprocta azarae & Sangue & Água Sumida \\
Akodon cursor & Sangue & Estreito de Cima (PEMD) \\
Akodon cursor & Sangue & Copacabana \\
Oligorizomys $s p$ & Sangue & Corredor agroflorestal \\
\hline
\end{tabular}




\section{DISCUSSÃO}

\subsection{CAPTURA DOS FLEBÓTOMOS}

Flebotomíneos são dípteros com grande importância em saúde pública, por serem os responsáveis pela veiculação de agentes patogênicos como os protozoários, vírus e bactérias (FORATTINI, 1973). Dentre estes patógenos, os tripanossomatídeos do gênero Leishmania sp adquirem grande destaque devido sua crescente incidência e expansão geográfica em diversas regiões do mundo, apresentando padrões epidemiológicos e fatores de risco diversos (DESJEUX, 2004).

Os flebotomíneos (Ordem: Diptera, Família: Psychodidae, Sub-família: Phlebotominae) apresentam ampla distribuição mundial, ocorrendo no Novo e Velho Mundo. Nas Américas existem cerca de 470 espécies descritas, sendo o Estado de São Paulo representado por aproximadamente 60 espécies (GOMES, 1994; GALATI, 2003).

Neste estudo registrou-se um total de 26 espécies de flebótomos. Este é o estudo que encontrou maior riqueza de espécies na região do Pontal do Paranapanema (FORATTINI, 1954; CONDINO et al., 1998; ALESSI et al., 2009). Espécies descritas em estudos anteriores (FORATTINI, 1954; CONDINO et al., 1998; ALESSI et al., 2009) também foram capturadas no presente estudo, em adição, houve o registro de duas espécies que não haviam sido descritas no Estado de São Paulo, Psathiromyia campograndensis e Evandromyia teratodes (SHIMABUKURU, 2007). Estas espécies tem sua distribuição, até então, associadas às regiões Norte e Centro-Oeste do Brasil, incluindo o Estado do Mato-Grosso do Sul, limite noroeste da região do Pontal.

Os trabalhos realizados anteriormente por Forattini (1954) e Condino et al. (1998) foram realizados no ambiente peridomiciliar, que comumente resultam em menor riqueza de espécies, quando comparado aos estudos em ambientes florestais, como é o caso deste trabalho (TOLEZANO et al., 2001). Além disso, o uso de armadilhas luminosas parece conferir maior riqueza de espécies em relação a armadilha de Shannon (GALATI et al., 1996).

A captura de um espécime de Bichromomyia flaviscutellata em armadilha instalada na borda de uma das áreas do Parque Estadual Morro do Diabo deve ser ressaltada devido sua grande importância vetorial na transmissão de Leishmania (Leishmania) amazonensis e por não ter sido descrita nos estudos anteriores realizados na região (FORATTINI, 1954; 
CONDINO et al., 1998; LAINSON; SHAW, 2005; ALESSI et al., 2009). Desta forma, a utilização de outras metodologias de coleta poderia fornecer maior representatividade da fauna flebotomínica local, contribuindo com o registro de espécies com hábitos mais antropofílicos ou zoofílicos, como é o caso da Bichromomyia flaviscutellata (DORVAL et al., 2007). Todavia, o uso de armadilhas luminosas tem se mostrado satisfatório para estudos que objetivam diversidade de espécies, mesmo que apresentem algumas limitações (GALATI et al., 1996; ALEXANDER, 2000; MASSAFERA et al., 2005; SILVA, A. et al., 2008; GALATI et al., 2006).

O Parque Estadual apresentou número de indivíduos e riqueza de espécies de flebotomíneos superiores ao dos fragmentos, semelhante ao que foi observado por Travi et al. (2002), em áreas de florestas tropicais intactas e alteradas na Colômbia.

Segundo Travi et al. (2002), a degradação florestal antrópica exerce influência negativa na abundância e diversidade de flebótomos. Este fato pôde ser observado no presente trabalho, embora em menor intensidade ao encontrado nas florestas tropicais da Colômbia. Apesar desta influência negativa, algumas espécies conseguem suportar os efeitos deletérios da degradação, apresentando apenas diminuição na sua abundância. Dentre estes efeitos deletérios podemos citar o aumento da penetração da luz solar, maior intensidade de vento, elevação da temperatura, aumento da evapotranspiração e a diminuição da umidade relativa do solo e do ar, podendo ter impacto no micro-habitat das formas imaturas e dos abrigos de adultos (FORATTINI, 1973; MURCIA, 1995; TURNER, 1996; STEVENS; HUSBAND, 1998; PACIÊNCIA; PRADO, 2004).

O gênero Brumptomyia sp exerceu dominância tanto no Parque Estadual como nos fragmentos se levarmos em conta todos os pontos de amostragem. As espécies do gênero Brumptomya sp são frequentemente abundantes em áreas florestais, muitas vezes associadas a tocas de animais, como tatus e roedores e com grande atração pela luz (FORATTINI, 1973; GALATI et al., 2003; DORVAL et al., 2009). No trabalho de Travi et al. (2002), a dominância de uma espécie para ambos os ambientes florestais, intactos ou degradados, também foi observada.

Analisando apenas os pontos de captura instalados na borda das áreas amostrais, pudemos observar clara dominância de Nyssomyia neivai no Parque Estadual, seguida por Nyssomyia withmani e Pintomyia pessoai, assim como observado por Forattini (1954) na década de 50, durante o período de desmatamento e colonização do município de Teodoro Sampaio. Na ocasião, o autor encontrou grande dominância do até então denominado Phebotomus intermedius, classificado posteriormente como Nyssomyia neivai 
(MARCONDES, 1996; ANDRADE FILHO et al., 2003), seguida pelas duas espécies mencionadas acima. As três espécies mais abundantes encontradas neste ponto estão incriminadas na transmissão da leishmaniose tegumentar.

Segundo Gomes (1992), a leishmaniose tegumentar é uma zoonose de caráter florestal e mesmo após o intenso desmatamento da Mata Atlântica no Estado de São Paulo, os remanescentes significativos ainda mantém o padrão de transmissão observado no início da colonização. Estes encontros demonstram que o Parque parece ter mantido o padrão de transmissão e distribuição das espécies vetoras, como foi observado no passado, corroborando ao que foi colocado por Gomes (1992) e observado por Condino et al. (1998). Estes fatos poderiam justificar a maior incidência humana da doença nas proximidades do Parque Estadual.

Alessi et al. (2009) observaram a dominância de Pintomyia pessoai e freqüência reduzida de Nyssomyia neivai no Parque Estadual Morro do Diabo. Porém, no trabalho de Alessi et al. (2009), o ponto de captura não foi realizado na borda, distante do ambiente domiciliar e peridomiciliar, que parece exercer influência determinante para a presença da Nyssomyia neivai (GOMES et al., 1983; GOMES, 1992. TOLEZANO, 1994). No Estado do Paraná, assim como no presente trabalho, Massafera et al. (2005) encontraram Nyssomyia neivai em frequência elevada na borda, próximo ao peridomicílio, sendo bastante reduzida a freqüência no interior da mata.

Nos fragmentos, o padrão observado no Parque parece ter sido alterado. O gênero Brumptomyia sp foi predominante, se considerarmos todos os pontos. No entanto, a presença de Nyssomyia neivai, comum nas bordas do Parque, não foi constatada na borda de nenhuma das seis áreas florestais representativas dos fragmentos.

A ausência de Nyssomyia neivai na borda dos fragmentos pode ser explicada pelo ponto de amostragem utilizado. Os pontos instalados na borda do Parque tinham em seu entorno, no caso do Estreito de Cima e no Estreito de Baixo, assentamentos da reforma agrária e um ribeirão, denominado Ribeirão Bonito. No caso da Perobeiras, terceira área amostral do Parque, o ponto estava próximo do Rio Paranapanema e de um barreiro, com a constante a presença de animais silvestres e humanos visitantes e funcionários do Parque Estadual. A presença de cursos d'água parece também ser um fator que predispõe a ocorrência e favorece a proliferação de Nyssomyia neivai, como foi observado por Odorizzi e Galati (2007), nas barrancas do Rio Aguapeí, pouco mais ao norte do município de Teodoro Sampaio, e por Forattini (1954), que encontrou formas imaturas nas margens de um córrego em Santo Anastácio, no Pontal do Paranapanema. 
No caso dos fragmentos, em geral, a borda amostrada estava delimitada por cultivos de cana-de-açúcar, pastagem e estrada, sem a presença de habitações humanas e animais domésticos nas proximidades. Além disso, estavam distantes dos cursos d'água e até mesmo ausentes no caso de alguns fragmentos. Para responder esta questão seria necessário amostrar as bordas dos fragmentos que estivessem próximas de ocupações humanas, assim como realizado no Parque.

Pelos dados deste trabalho, podemos considerar que o processo de fragmentação florestal no Pontal parece exercer efeito deletério nas populações de Nyssomyia neivai. No entanto, o ciclo enzoótico e peridomiciliar da doença poderia ser mantido por Nyssomyia withmani e Pintomyia pessoai, espécies reconhecidamente vetoras na transmissão da leishmaniose cutânea e que se mantiveram nos ambientes florestais fragmentados do Pontal.

\subsection{PESQUISA DE Leishmania sp NOS FLEBÓTOMOS}

As leishmanioses tegumentares são consideradas pela Organização Mundial da Saúde uma das seis doenças infecciosas mais importantes no ser humano, devido sua alta incidência e impacto psicossocial, pelo potencial de produzir deformidades no indivíduo (BRASIL, 2007). Nas Américas, onze espécies são incriminadas na etiologia da doença, com sete delas encontradas no Brasil. Todas as leishmanioses são transmitidas por flebotomíneos e o perfil epidemiológico da doença está diretamente relacionado à ecologia desses vetores, que podem se favorecer de algumas circunstâncias proporcionadas pelas alterações ambientais causadas pelo homem (ASHFORD, 2000; BRASIL, 2007).

As fêmeas dos flebotomíneos adquirem o parasita na forma amastigota, ao realizarem o repasto sanguíneo no mamífero reservatório. No vetor, os parasitas se encontram, sob a forma promastigota e dependendo do local de seu desenvolvimento no trato digestório do inseto, são classificadas pelo subgênero Leishmania e Viannia (LAINSON; SHAW, 2005).

Para que uma espécie de flebotomíneo possa ser considerada vetora da leishmaniose alguns requisitos devem ser obedecidos, como distribuição geográfica compatível com os casos da doença, competência vetorial, alta densidade populacional e o encontro do parasito no interior do vetor. Muitas vezes, nem todos os requisitos conseguem ser preenchidos, principalmente no que se refere ao encontro do parasito no vetor. 
A observação de flebotomíneos naturalmente infectados em áreas endêmicas, assim como a identificação da espécie de Leishmania sp encontrada nas espécies de flebotomíneos são ferramentas de grande importância em estudos vetoriais e na epidemiologia da leishmaniose.

O método comumente utilizado para pesquisa de Leishmania sp no vetor é a dissecção de seu trato digestório (PESSOA; COUTINHO, 1941; FORATTINI, 1954; GALATI et al., 1996). Porém, este método demanda muito tempo, é laborioso e necessita da perícia do observador e da manutenção do inseto vivo até dissecção. Além disso, muitas vezes a identificação torna-se inviável devido a necessidade de isolamento e caracterização do flagelado, sendo a identificação feita até o subgênero, Leishmania ou Viannia, pela localização dos protozoários no trato digestório do vetor (GALATI et al., 1996). Tendo em vista estes fatos, técnicas moleculares para pesquisa de Leishmania sp tem sido cada vez mais utilizadas em estudos epidemiológicos e para avaliação da capacidade vetorial de flebotomíneos (MICHALSKY et al., 2002; PITA-PEREIRA et al., 2005; SILVA, E. et al., 2008).

A investigação da freqüência de infecção natural por flagelados em espécies de flebotomíneos, seja por dissecção ou por PCR, apresentam resultados variáveis (PESSOA; COUTINHO et al., 1941; GALATI et al., 1996; SILVA, E. et al., 2008; MARCONDES et al., 2009; PITA-PEREIRA et al., 2005; DE CARVALHO et al., 2010). No entanto, a PCR apresenta maior sensibilidade em relação à dissecção (PAIVA et al., 2006).

Neste trabalho, foi realizada a PCR de 872 indivíduos, distribuídos em 90 pools de um a 20 indivíduos, separados por espécie e local de captura e todas as amostras apresentaram resultados negativos, sugerindo baixa frequência da infecção natural em flebotomíneos por parasitos do gênero Leishmania sp na região do Pontal, assim como foi verificado por Forattini (1954), que encontrou formas leptomonas em flebótomos com uma freqüência de 0,12\% dentre 782 examinados, das espécies Phlebotomus intermedius e Phebotomus withmani. Em outras regiões endêmicas, através da dissecção, Pessoa e Coutinho (1941) encontraram uma freqüência de infecção por leptomonas em torno de $0,2 \%$ nas espécies Nyssomyia withmani, Pintomyia pessoai e Migonemyia migonei, no Estado de São Paulo e Galati et al. (1996) verificaram uma taxa de infecção por flagelados de 0,16\% em Nyssomyia withmani no Estado do Mato Grosso do Sul.

Os dados deste trabalho devem ser considerados plausíveis se levarmos em conta que estudos anteriores também encontraram baixa freqüência de infecção por Leishmania sp. Somado a isso, neste trabalho, foram utilizadas além de espécies conhecidamente vetoras, 
outras espécies que até então parecem não possuir competência vetorial, sem provável importância epidemiológica para as leishmanioses.

Contudo, algumas considerações devem ser levantadas sobre a metodologia utilizada. A extração do DNA foi realizada utilizando o Kit da Qiagen ${ }^{\circledR}$ DNAeasy Blood e Tissue. Segundo o fabricante, este kit é apropriado para uso em insetos e a extração foi feita seguindo as instruções informadas no manual. Antes da escolha deste kit como método para extração, foi realizado um teste com 5 pools de 10 flebotomíneos, da espécie Nyssomyia neivai. Após quantificação em espectrofotometria, a razão de absorbância e a quantidade do DNA se mostraram adequadas para a realização da PCR. A formação de pools é comumente utilizada como forma de diminuir o número de amostras a serem processadas, tendo em vista que geralmente o número de flebotomímeos capturados é elevado, inviabilizando a realização da PCR por indivíduo e parece não influenciar na detecção do DNA de Leishmania sp (PITAPEREIRA et al., 2005; SILVA E., et al., 2008). Quanto ao armazenamento, Segundo Cabrera et al. (2002) o álcool 70\% é o método que apresenta o melhor custo-benefício para estocagem de flebotomíneos antes da realização da PCR. O protocolo de PCR utilizado foi adequado tendo em vista que os controles positivos, oriundos de amostras de cultura foram amplificados.

Desta forma, o próximo passo, que não foi possível lançar mão durante a realização deste projeto, mas será realizado para fins de publicação, é a utilização de marcadores moleculares específicos para flebotomíneos para certificação do sucesso da extração do DNA e da possível presença de inbidores da PCR (PEIXOTO et al., 2001).

\subsection{PESQUISA DE Leishmania sp NOS MAMÍFEROS}

As leishmanioses tegumentares são zoonoses causadas pelos protozoários da Ordem Kinetoplastida, família Tripanossomatidae, gênero Leishmania, que possui ciclo de vida heteroxênico, envolvendo um mamífero e um vetor artrópode. Nas Américas, onze espécies são atualmente incriminadas na etiologia da doença, apresentando diferentes padrões epidemiológicos, influenciados pelas características ecológicas de seus vetores e mamíferos reservatórios (GONTIJO; CARVALHO, 2003; BASANO; CAMARGO, 2004).

Primariamente, as leishmanioses estavam restritas ao ambiente silvestre onde mamíferos selvagens como roedores, marsupiais, primatas, xenarthras e carnívoros atuavam 
como reservatórios para o vetor (LAINSON; SHAW, 2005). Acreditava-se que com a remoção da cobertura florestal, a leishmaniose tenderia ao desaparecimento no Estado de São Paulo (SAMPAIO, 1951). No entanto, após anos de colonização e desmatamento, a incidência da leishmaniose tem aumentado, com a adaptação dos vetores e reservatórios aos fragmentos residuais de mata (GOMES, 1992).

A atividade reservatória de roedores e marsupiais silvestres na ecologia da leishmaniose tegumentar já foi relatada por diversos autores nas Américas, sugerindo que os mesmos estejam incriminados na manutenção do ciclo silvestre e peridoméstico da doença (FORATTINI, 1960; NERY-GUIMARÃES; COSTA, 1966; LAINSON; SHAW, 1969, 1970; FORATTINI et al., 1972, 1973; LAINSON; SHAW, 2005; TOLEZANO et al., 1988; DE LIMA et al., 2002; BRANDÃO-FILHO, 2003).

Neste trabalho observamos a positividade para Leishmania sp em quatro espécies de mamíferos selvagens, Didelphis albiventris, Akodon cursor, Dasyprocta azarae e Oligorizomys sp, reafirmando o papel dos roedores e marsupiais no ciclo silvestre da leishmaniose na região do Pontal, assim como foi observado por Forattini (1960).

Didelphis albiventris foi a espécie mais freqüente, capturada em todas as áreas estudadas. Segundo Emmons e Feers (1997), é um marsupial onívoro, que habita desde áreas florestais primárias e secundárias, até zonas rurais e centros urbanos. Tem atividade crepuscular e noturna, buscando abrigos em ocos de árvore, entre suas raízes, ou debaixo de troncos caídos. Devido ao seu comportamento generalista e sua maior biomassa, esta espécie tende a dominar em fragmentos pequenos eliminando seus competidores por predação ou na disputa por recursos, possuindo grande movimentação em paisagens fragmentadas (FONSECA; ROBINSON, 1990; PIRES et al., 2002). Pelo seu caráter sinantrópico e capacidade de adaptação em áreas alteradas, Didelphis albiventris é muitas vezes alvo potencial em pesquisas sobre reservatórios de Leishmania sp. (YOSHIDA et al., 1979; ALEXANDER et al., 1998; SILVA et al., 2001; BRANDÃO-FILHO, 2003; SANTIAGO et al., 2007).

Quintal (2010) encontrou em amostras de pele de Didelphis albiventris da mesma região deste estudo, utilizando PCR convencional e PCR tempo real, uma positividade de $0 \%$ e 1,65\%, respectivamente. Para a espécie Micoureus paraguayanus, a prevalência foi de $7,45 \%$ e $10,6 \%$ pelo PCR convencional e em PCR tempo real, respectivamente. No presente trabalho, espécimes de Micoureus paraguayanus foram amostrados sem apresentar positividade, porém, o tamanho da amostra utilizada para esta espécie foi consideravelmente menor e certamente pode ter influenciado nos resultados. A freqüência de animais positivos 
para Leishmania sp observada para Didelphis albiventris neste trabalho foi de 2,44\%. Dos quatro indivíduos positivos, dois pertenciam ao fragmento Copacabana.

A atividade reservatória de roedores do gênero Akodon sp já foi relatada por Forattini et al. (1972); Rocha et al. (1988) e Tolezano et al. (1988), que encontraram indivíduos deste gênero naturalmente infectados no Estado de São Paulo e Minas Gerais. Segundo Oliveira e Bonvicino (2006), os roedores deste gênero ocorrem tanto em áreas florestais como em áreas abertas na Mata Atlântica, Cerrado, Caatinga e Campos do Sul, vivendo em galerias construídas sob a camada de folhas em decomposição, possuindo hábitos noturnos. Algumas espécies tendem a ser mais abundantes, como é o caso do Akodon cursor, com pouca movimentação em paisagens fragmentadas (PIRES et al., 2002). Neste trabalho, esta espécie foi a segunda mais abundante, capturada em praticamente todas as áreas, com exceção da Perobeiras no Parque Estadual Morro do Diabo. Forattini (1960) investigando a presença de Leishmania sp em animais silvestres na região do Pontal, capturou 928 mamíferos, sendo o gênero Akodon um dos mais freqüentes dentre os roedores, assim como observado neste trabalho. Porém, não observou qualquer tipo de infecção. No presente estudo, dois indivíduos apresentaram positividade para Leishmania sp na PCR, em amostras de sangue, sendo um capturado no Parque e o outro no fragmento Copacabana.

Os primeiro relatos de roedores do gênero Dasyprocta apresentando sugestivas lesões leishmanióticas foram realizados no início do século, no Estado de São Paulo por Brumpt e Pedroso $^{1}$ (1913 apud FORATTINI, 1960, p. 197). Posteriormente, Forattini (1960) evidenciou um espécime de Dasyprocta azarae apresentando lesão no focinho, na região de Teodoro Sampaio, sendo observadas formas leishmanicas em cortes histológicos e esfregaços. Em nível de curiosidade, segundo a descrição do local de captura deste espécime pelo autor, podemos constatar se tratar do Parque Estadual Morro do Diabo, muito próximo da área amostral Perobeiras. No presente trabalho, foi capturado um indivíduo desta espécie que apresentou resultado positivo na PCR da amostra de sangue, no fragmento Água Sumida.

O indivíduo do gênero Oligoryzomys sp que apresentou positividade foi capturado em um corredor agroflorestal, onde está sendo realizada a restauração florestal, com objetivo de conexão entre dois fragmentos florestais da região. Até o presente momento não foram encontradas referências que relacionam este gênero à infecção por Leishmania sp. Desta forma, mais estudos devem ser conduzidos para elucidar qual é a espécie do roedor, assim como qual o potencial do corredor como via de dispersão da leishmaniose na paisagem.

\footnotetext{
${ }^{1}$ BRUMPT, E.; PEDROSO, A. M. Pesquisa Epidemiológica sobre a leishmaniose americana das florestas no Estado de São Paulo (Brasil). Anais Paulistas de Medicina e Cirurgia, v. 1, p. 97-132, 1913.
} 
Apesar de observarmos a amplificação do fragmento de DNA da Leishmania sp correspondente ao produto da PCR nas amostras analisadas neste trabalho, somado a grande sensibilidade dos marcadores moleculares utilizados frente a outros métodos diagnósticos (BENSOUSSAN et al., 2006), a incriminação de espécies como reservatórias de Leishmania sp deve ser utilizada com cautela. Os resultados deste trabalho apenas sugerem o envolvimento de algumas espécies no ciclo silvestre da leishmaniose no Pontal, sendo que, para sua comprovação, devemos realizar estudos mais aprofundados de competência reservatória, envolvendo infecções experimentais, xenodiagnóstico, capacidade de infecção para o vetor, carga parasitária e localização do parasita, suscetibilidade, longevidade, assim como estudos populacionais relacionados à abundância e sazonalidade do hospedeiro.

A fragmentação florestal parece não influenciar na freqüência de infecção das espécies de mamíferos, visto que um representante de cada área amostral categorizada por tamanho apresentou indivíduos positivos, sem diferença estatística significativa. Desta forma, com os resultados deste trabalho, podemos considerar que os fragmentos florestais tem potencial para manter o ciclo silvestre da doença, corroborando com o que foi colocado por Gomes (1992). 


\section{CONCLUSÃO}

A partir dos resultados encontrados, podemos concluir que:

- O gênero Brumptomyia foi o mais abundante nos ambientes florestais do Pontal;

- Nyssomyia neivai foi a espécie mais abundante na borda do Parque Estadual Morro do Diabo;

- Nyssomyia neivai esteve ausente nos pontos instalados na borda dos fragmentos;

- Foram encontradas duas novas espécies de flebotomíneos no Estado de São Paulo, Psathyromyia campograndensis e Evandromyia teratodes;

- Foram encontrados Didelphis albiventris, Dasyprocta azarae, Akodon cursor e Oligoryzomys sp portando parasitos do gênero Leishmania;

- Não houve diferença significativa na freqüência de mamíferos infectados por Leishmania sp em relação ao tamanho das áreas florestais no Pontal. 


\section{REFERÊNCIAS}

AGUILAR, C. M.; FERNANDEZ, E.; FERNANDEZ, R.; DEANE, L. M. Study of an outbreak of cutaneous leishmaniasis in Venezuela. The role of domestic animals. Memórias do Instituto Oswaldo Cruz, v. 79, n. 2, p. 181-195, 1984.

AGUILAR, C. M.; RANGEL, E. F.; GARCIA, L.; FERNANDEZ, E.; MOMEN, H.; GRIMALDI FILHO, G.; VARGAS, Z. Zoonotic Cutaneous Leishmaniasis due to Leishmania (Viannia) braziliensis associated with domestic animals in Venezuela and Brazil. Memórias do Instituto Oswaldo Cruz, v. 84, n. 1, p. 19-28, 1989.

ALESSI, C. A. C.; GALATI, E. A. B.; ALVES, J. R.; CORBETT, C. E. P. American Cutaneous Leishmaniasis in the Pontal of Paranapanema-SP, Brazil: Ecological and entomological aspects. Revista do Instituto de Medicina Tropical de São Paulo, v. 51, n. 5, p. $277-282,2009$.

ALEXANDER, B. Sampling methods for phebotominae sandflies. Medical and Veterinary Entomology, v. 14, p. 109-122, 2000.

ALEXANDER, B.; LOZANO, C.; BARKER, D. C.; McCANN, S. H. E.; ADLER, G. H. Detection of Leishmania braziliensis complex in wild mammals from Colombian coffe plantations by PCR and DNA hybridization. Acta tropica, v. 69, p. 41-50, 1998.

ALLAN, B. F.; KESSING, F.; OSTFELD, R. S. Effect of forest fragmentation on Lyme disease risk. Conservation Biology, v. 17, n. 1, p. 267-272, 2003.

ANDRADE FILHO, J. D.; GALATI, E. A. B.; FALCÃO, A. L. Redescription of Nyssomyia intermedia (Lutz \& Neiva, 1912) and Nyssomyia neivai (Pinto, 1926) (Diptera: Psychodidae). Memórias do Instituto Oswaldo Cruz, v. 98, n. 8, p. 1059-1065, 2003.

ASHFORD, R. W. The leishmaniasis as emerging and reemerging zoonoses. International Journal for Parasitology, v. 30, p. 1269-1281, 2000.

AUSUBEL, R. B., R. E.; KINGSTON, MOORE, D.; SEIDMAN J. G.;, SMITH J. A.; STRUHL, K. Short protocols in molecular biology., 4th ed. New York: John Wiley \& Sons, 1999.

BAILEY, M. S.; LOCKWOOD, D. N. J. Cutaneous leishmaniasis. Clinics in Dermatology, v. 25, p. 203-211, 2007. 
BASANO, S. A.; CAMARGO, L. M. A Leishmaniose Tegumentar Americana: histórico, epidemiologia e perspectivas de controle. Revista Brasileira de Epidemiologia, v. 7, n. 3, p. 328-37, 2004.

BENSOUSSAN, E.; NASEREDDIN, A.; JONAS, F.; SCHNUR, L. F.; JAFFE, C. L. Comparison of PCR Assays for Diagnosis of Cutaneous Leishmaniasis. Journal of Clinical Microbiology, v. 44, n. 4, p. 1435-1439, 2006.

BRANDÃO-FILHO, S. P.; BRITO, M. E.; CARVALHO, F. G.; ISHIKAWA, E. A.; CUPOLILLO, E.; FLOETER-WINTER, L.; SHAW, J. Wild and synantrophic hosts of Leishmania (Viannia) braziliensis in the endemic cutaneous leishmaniasis locality of Amaraji, Pernambuco State, Brazil. Transactions of the Royal Society of Tropical Medicine and Hygiene, v. 97, p. 291-296, 2003.

BRASIL. MINISTÉRIO DA SAÚDE. Manual de Vigilância da Leishmaniose Tegumentar Americana. Brasília, 2007. 182 p.

BROWN K. S.; BROWN, G. G. Habitat Alteration and species loss in brazilian forests. In: WHITMORE, T. C.; SAYER, J. A. (Ed.). Tropical deforestation and species extinction. Londres: Chapman \& Hall, 1994. p. 119-142, 1994.

CAMARGO-NEVES, V. L.; GOMES, A. C.; ANTUNES, J. L. F. Correlação da presença de flebotomíneos com registros de casos da Leishmaniose Tegumentar Americana. Revista da Sociedade Brasileira de Medicina Tropical, v. 35, n. 4, p. 299-306, 2002.

CABRERA, O. L., MUNSTERMAN, L.E., CARDENAS, R., GUTIERREZ, R., FERRO, C. Definition of appropriate temperature and storage conditions in the detection of Leishmania DNA with PCR in phlebotomine flies. Biomedica (Bogota) v. 22, n. 3, p. 296-302, 2002

CHIARELLO, A. G. Effects of fragmentation of the Atlantic forest for mammal communities in south-eastern Brazil. Biological Conservation, v. 89, p. 71 -82, 1999.

CONDINO, M. L. F.; SAMPAIO, S. M. P.; HENRIQUES, L. F.; GALATI, E. A. B.; WANDERLEY, D. M. V.; CORRÊA, F. M. A. Leishmaniose Tegumentar Americana: flebotomíneos de área de transmissão no município de Teodoro Sampaio, região sudoeste do Estado de São Paulo, Brasil. Revista da Sociedade Brasileira de Medicina Tropical, v. 31, n. 4, p. 355-360, 1998.

DASZAK, P.; EPSTEIN, J.; KILPATRICK, A. M.; AGUIRRE, A. A.; KARESH, W. B.; CUNNINGHAN, A. A. Collaborative research approaches to the role of wildlife in zoonotic disease emergence. Current topics in Microbiology and Immunology, v. 315, p. 463-475, 2007. 
DE CARVALHO, M. R.; VALENÇA, H. F.; SILVA, F. J.; PITA-PEREIRA, D.; PEREIRA, T. A.; BRITTO, C.; BRAZIL, R. P.; BRANDÃO-FILHO, S. Natural Leishmania infantum infection in Migonemyia migonei (Díptera: Psychodidae: Phlebotominae) the puctative vector of visceral leishmaniasis in Pernambuco State, Brazil. Acta tropica, 2010.

DE LIMA, H.; DE GUGLIELMO, Z.; RODRÍGUEZ, A.; CONVIT, J.; RODRIGUEZ, N. Cotton Rats (Sigmodon hispidus) and Black Rats (Rattus rattus) as possible reservoirs of Leishmania spp. in Lara State, Venezuela. Memórias do Instituto Oswaldo Cruz, v. 97, n. 2, p. 169-174, 2002.

DESJEUX, P. Leishmaniasis: current situation and new perspectives. Comparative Immunology, Microbiology \& Infectious Diseases, v. 27, p. 305-318, 2004.

DITT, E. H. Fragmentos florestais no Pontal do Paranapanema. 1. ed. São Paulo: Annablume, 2002. v. 1, 140 p.

DORVAL, M. E. C.; ALVES, T. P.; OLIVEIRA, A. G.; BRAZIL, R. P.; GALATI, E. A. B.; CUNHA, R. V. Modification of Disney trap for capture of sand flies (Diptera: Psichodidae: Phebotominae). Memórias do Instituto Oswaldo Cruz, v. 102, n. 7, p. 877-878, 2007.

DORVAL, M. E. C.; CRISTALDO, G.; ROCHA, H. C.; ALVES, T. P.; ALVES, M. A.; OSHIRO, E. T.; OLIVEIRA, A. G.; BRAZIL, R. P.; GALATI, E. A. B.; CUNHA, R. V. Phlebotomine fauna (Díptera: Psychodidae) of an American Cutaneous leishmaniasis endemic area in the State of Mato Grosso do Sul, Brazil. Memórias do Instituto Oswaldo Cruz, v. 104, n. 5, p. 695-702, 2009.

EMMONS, L.H.; FEER, F. Neotropical rainforest mammals. Chicago and London, The University of Chicago Press, 2nd. ed., 307 p. 1997.

FALQUETO, A.; COURA, J. R.; BARROS, G. C.; GRIMALDI FILHO, G.; SESSA, P. A.; CARIAS, V. R. D.; JESUS, A. C.; ALENCAR, J. T. A. Participação do cão no ciclo de transmissão da leishmaniose tegumentar no município de Viana, Estado do Espírito Santo, Brasil. Memórias do Instituto Oswaldo Cruz, v. 81, n. 2, p. 155-163, 1986.

FERRARI LEITE, J. A ocupação do Pontal do Paranapanema. 1998. Tese (de Doutorado) - Universidade Estadual Paulista (UNESP), Presidente Prudente, SP, 1998.

FORATTINI, O. P. Algumas observações sobre a biologia de flebótomos em região da Bacia do Rio Paraná (Brasil). Arquivos de Higiene e Saúde Pública, v. 8, p. 15-136, 1954.

FORATTINI, O. P. Entomologia Médica. Psychodidae. Phlebotominae. Leishmanioses. Bartonelose., São Paulo: Ed. Edgard Blücher, 1973. 658 p. 
FORATTINI, O. P. Notas sobre criadouros naturais de flebotomíneos em dependências peridomiciliares no Estado de São Paulo Arquivos da Faculdade de Higiene e Saúde Pública da Universidade de São Paulo, v. 7, n. 2. p. 157-167, 1953.

FORATTINI, O. P. Sobre os reservatórios naturais da Leishmaniose Tegumentar Americana. Revista do Instituto de Medicina Tropical de São Paulo, v. 2, n. 4, p. 195-203, 1960.

FORATTINI, O. P.; PATTOLI, D. B. G.; RABELLO, E. X.; FERREIRA, O. A. Infecções naturais de mamíferos silvestres em área endêmica de leishmaniose do Estado de São Paulo, Brasil. Revista de Saúde Pública, v. 6, p. 255-261, 1972.

FORATTINI, O. P.; PATTOLI, D. B. G.; RABELLO, E. X.; FERREIRA, O. A. Nota sobre infecção natural de Oryzomys capito laticeps em foco enzoótico de leishmaniose tegumentar no Estado de São Paulo, Brasil. Revista de Saúde Pública, v. 7, p. 477-52, 1973a.

GALATI, E. A. B.; NUNES, V. L. B.; DORVAL, M. E. C.; OSHIRO, E. T.; CRISTALDO, G.; ESPÍNDOLA, M. A.; ROCHA, H. C.; GARCIA, W. B. Estudo de flebotomíneos (Díptera, Psichodidae), em área de leishmaniose tegumentar, no Estado do Mato Grosso do Sul, Brazil. Revista de Saúde Pública, v. 30, n. 2, p. 115-28, 1996.

GALATI, E. A. B. Classificação de phlebotominae. In: RANGEL, E. F.; LAINSON, R. Flebotomíneos do Brasil. Rio de Janeiro:, Editora FIOCRUZ, 2003. p. 23-51.

GALATI, E. A. B. Morfologia, terminologia de adultos e identificação dos táxons da América. In: RANGEL, E. F.; LAINSON, R. Flebotomíneos do Brasil. Rio de Janeiro: Fiocruz, 2003. p. 53-175.

GALATI, E. A. B.; NUNES, V. L. B.; BOGGIANI, P. C.; DORVAL, M. E. C.;

CRISTALDO, G.; ROCHA, H. C.; OSHIRO, E. T.; DAMASCENO Jr., G. A. Phebotomines (Díptera: Psychodidae) in forested areas of the Serra da Bodoquena, state of Mato Grosso do Sul, Brazil. Memórias do Instituto Oswaldo Cruz, v. 101, n. 2., p. 175-193, 2006.

GOMES, A. C. Perfil epidemiológico da leishmaniose tegumentar no Brasil. Anais Brasileiros de Dermatologia, v. 67, n. 2, p. 55-60, 1992.

GOMES, A. C.; RABELLO, E. X.; SANTOS, J. L. F.; GALATI, E. A. B. Aspectos ecológicos da leishmaniose tegumentar americana: 3) Observações naturais sobre o ritmo diário da atividade de Psychodopygus intermedius em ambiente florestal e extraflorestal. Revista de Saúde Pública, v. 17, p. 23-30, 1983.

GOMES, A. C.; COUTINHO, S. G.; PAIM, G. V.; OLIVEIRA, S. M. O.; GALATI, E. A. B.; NUNES, M. P.; CAPINZAIKI, A. N.; YAMAMOTO, Y. I.; ROTTER, P. Aspectos ecológicos da leishmaniose tegumentar americana: 8) Avaliação da atividade enzoótica de 
Leishmania (Viannia) braziliensis, em ambiente florestal e domiciliar, no Vale do Ribeira, Estado de São Paulo, Brasil. Revista do Instituto de Medicina Tropical de São Paulo, v. 32, n. 2, p. 105-115, 1990.

GONTIJO, B.; CARVALHO, M. L. R. Leishmaniose Tegumentar Americana. Revista da Sociedade Brasileira de Medicina Tropical, v. 36, n. 1, p. 71-80, 2003.

HADDOW A. J. Studies on the biting habits and medical importance of East African mosquitoes in the genus Aedes. I- Subgenera Aedimorphus, Banksinella and Nunnius. Bulletin of Entomological Research, v. 50, p. 759-779, 1960.

HAYEK L-A. C.; BUZAS, M. A. Surveying natural population. New York: Columbia University Press, 1997. p. 347-377.

LAINSON, R. ; SHAW, J. J. New World Leishmaniasis. In: COX, F.EG Cox; WAKELIN, D.; GILlESPIE, S. H.; DESPOMMIER, D. D. (Org.). Topley \& Wilson Microbiology and Microbial Infections. 10. ed. London: Hodder Arnold, 2005. chap. 17, v. 2, p. 313-349.

LAINSON, R.; SHAW, J. J. Leishmaniasis in Brazil. III - Cutaneous leishmaniasis in a opossum Marmosa murina (Marsupialia, Didelphidae) from the lower Amazon region. Transactions of the Royal Society of Tropical Medicine and Hygiene, v. 63, p. 738-740, 1969.

LAINSON, R.; SHAW, J. J. Leishmaniasis in Brazil. V - Studies on the epidemiology of cutaneous leishmaniasis in Mato Grosso State, and observations on two distinct strains of Leishmania isolated from man and forest animals. Transactions of the Royal Society of Tropical Medicine and Hygiene, v. 64, p. 654-667, 1970.

LOGIUDICE, K.; OSTFELD, R. S; SCHMIDT, K. A; KESSING, F. The ecology of infectious disease: Effects on host diversity and community composition in Lyme disease risk. Proccedings of the National Academy of Sciences of the United States of America, v. 100, n. 2, p. 567-571, 2003.

MARCONDES C. B. A redescription of Lutzomyia (Nyssomyia) intermedia (Lutz \& Neiva,1912), and resurrection of L. neivai (Pinto, 1926) (Diptera, Psychodidae, Phlebotominae). Memórias do Instituto Oswaldo Cruz, v. 91, n. 3, p. 457-462, 1996.

MARCONDES, C. B.; BITTENCOURT, I. A.; STOCO, P. H.; EGER, I.; GRISARD, E. C.; STEINDEL, M. Natural infection of Nyssomyia neivai (Pinto, 1926) (Diptera, Psychodidae, Phlebotominae) by Leishmania (Viannia) spp in Brazil. Transactions of the Royal Society of Tropical Medicine and Hygiene, v. 103, p. 1093 - 1097, 2009. 
MASSAFERA, R.; SILVA, A. M.; CARVALHO, A. P.; SANTOS, D. R.; GALATI, E. A. B.; TEODORO, U. Fauna de flebotomíneos do Município de Bandeirantes, no Estado do Paraná. Revista de Saúde Pública, v. 39, n. 4, p. 571-7, 2005.

MICHALSKY, E. M.; FORTES-DIAS, C. L.; PIMENTA, P. F. P.; SECUNDINO, N. F. C.; DIAS, E. S. Assessment of PCR in the detection of Leishmania spp in experimentally infected individual phlebotomine sandflies (Diptera: Psychodidae: Phlebotominae). Revista do Instituto de Medicina Tropical de São Paulo, v. 44, n. 5, p. 255-259, 2002.

MURCIA, C. Edge effects in fragmented forests: implications for conservation. Trends in Ecology \& Evolution, v. 10, n. 2, p. 58-62, 1995.

NERY-GUIMARÃES, F.; COSTA, O. R. Novas observações sobre a Leishmania isolada de Oryzomys goeldi na Amazônia. Hospital, v. 69, p. 185-192, 1966.

ODORIZZI, R. M. F. N.; GALATI, E. A. B. Flebotomíneos de várzea do Rio Aguapeí, região Nordeste do Estado de São Paulo, Brasil. Revista de Saúde Pública, v. 41, n. 4, p. 645-52, 2007.

OLIVEIRA, J. A.; BONVICINO, C. R. Ordem Rodentia. In: REIS, N. R.; PERACCHI, A. L.; PEDRO, W. A.; LIMA, I. P. Mamíferos do Brasil. Londrina: Ed. Londrina, 2006. 437p.

OLIVEIRA, F. S.; PIRMEZ, C.; PIRES, M. Q.; BRAZIL, R. P.; PACHECO, R. S. PCRbased diagnosis for detection of Leishmania in skin and blood of rodents from an endemic area of cutaneous and visceral leishmaniasis in Brazil. Veterinary Parasitology, v. 129, p. 219-227, 2005.

OSTFELD, R. S.; KESSING, F. The function of biodiversity in the ecology of vector borne zoonotic diseases. Canadian Journal of Zoology, v. 78, p. 2061-2078, 2000.

PACIENCIA, M. L. B.; PRADO, J. Efeito de borda sobre a comunidade de pteridófitas na região de Una, sul da Bahia, Brasil. Revista Brasileira de Botânica, v. 27, n. 4, p. 641-653, 2004.

PAIVA, B. R.; SECUNDINO, N. F. C.; NASCIMENTO, N. C.; PIMENTA, P. F. P.; GALATI, E. A. B.; ANDRADE JUNIOR, H. F.; MALAFRONTE, R. S. Detection and identification of Leishmania species in field-captured phlebotomine sandflies based on miniexon gene PCR. Acta tropica, v. 99, p. 252-259, 2006. 
PATZ, J. A.; GRACZYC, T. K.; GELLER, N.; VITTOR, A. Y Effects of environmental changes on emerging parasitic diseases. International Journal for Parasitology, v. 30, p. 1395-1405, 2000.

PEIXOTO, A. A.; GOMES, C. A.; DE AMORETTY, P. R.; LINS, R. M. M. A.; MEIRELESFILHO, A. C. A.; SOUZA, N. A.; KYRIACOU, C. P. New molecular markers for phlebotomine sandlfies. International Journal for Parasitology, v. 31, p. 635-639, 2001.

PESSÔA S. B.; PESTANA B. R. Sobre a disseminação da leishmaniose tegumentar no Estado de São Paulo. Arquivos de Higiene e Saúde Pública, v. 8, p. 37-46, 1940.

PESSOA, C. A. Rodentia - Roedores de companhia. In: CUBAS, Z. S.; SILVA, J. C. R.; CATÃO-DIAS, J. L. Tratado de animais selvagens - Medicina veterinária. São Paulo: Roca, 2006. p. 432-474.

PESSOA, S. B.; COUTINHO, J. O. Infecção natural e experimental dos flebótomos pela Leishmania braziliensis, no Estado de São Paulo. O Hospital, v. 20, p. 25-35, 1941.

PETERSON, A. T.; SHAW, J. Lutzomyia vectors for cutaneous leishmaniais in Southern Brazil: ecological niche models, predicted geographic distributions, and climate change effects. International Journal for Parasitology, v. 33, p. 919-31, 2003.

PIRES, A. S.; LIRA, P. K.; FERNANDEZ, F. A. S.; SCHITTINI, G. M.; OLIVEIRA, L. C. Frequency of movements of small mammals among Atlantic Coastal Forest Fragments in Brazil. Biological Conservation, v. 108, p. 229-307, 2002.

PITA-PEREIRA, D.; ALVES, C. R.; SOUZA, M. B.; BRAZIL, R. P.; BERTHO, A. L.; BARBOSA, A. F.; BRITTO, C. C. Identification of naturally infected Lutzomyia intermedia and Lutzomyia migonei with Leishmania (Viannia) braziliensis in Rio de Janeiro (Brazil) revealed by a PCR multiplex non-isotopic hybridisation assay. Transactions of the Royal Society of Tropical Medicine and Hygiene, v. 99, p. 905-13, 2005.

PONÇANO, W. L.; CARNEIRO, C. D. R.; BISTRICHI, C. A.; ALMEIDA, F. F. M. PRANDINI, F. L. Mapa geomorfológico do Estado de São Paulo. São Paulo: v. 1. IPT Instituto de Pesquisas Tecnológicas, São Paulo, 1981. v. 1.

QUINTAL, A. P. N. Leishmania spp. em reservatórios marsupiais Didelphis albiventris e Micoureus paraguayanus. 2010. 47p. Dissertação (Mestrado em Ciência Animal) apresentada à- Faculdade de Odontologia, UNESP, Araçatuba, 2010.

REITHINGER, R.; DAVIES, C. R. Is the domestic dogs (Canis familiaris) a reservoir host of american cutaneous leishmaniasis? A critical review of the current evidence. American Journal of Tropical Medicine and Hygiene, v. 61, n. 4, p. 530-541, 1999. 
ROBERTS D. R.; HIS, B. P. An index of species abundance for use with mosquito survillance data. Environmental Entomology, v. 8, p. 1007-1013, 1979.

ROCHA, F. S. A conservação de pequenos mamíferos no Pontal do Paranapanema, São Paulo: diagnóstico de padrões de comunidades e sugestões de manejo. 2004. 127 p.Tese (Doutorado em Ciências) - Instituto de Biociências, Universidade de São Paulo, São Paulo, 2004.

ROCHA, M. M.; MELO, M. N.; BABFI, E. H.; DIAS, M. S. M.; MICHALICK, M. S. M.; DA COSTA, C. A.; WILLIAMS, P.; MAYRINK, W. Leishmania braziliensis braziliensis isolated from Akodon arviculoides captured in Caratinga, Minas Gerais, Brazil. Transactions of the Royal Society of Tropical Medicine and Hygiene, v. 82, p. 68, 1988.

RODGERS, M. R.; POPPER, S. J.; WIRTH, D. F. Amplification of Kinetoplast DNA as a Tool in the Detection and Diagnosis of Leishmania. Experimental Parasitology, v. 71, n. 3, 267-75, 1990.

RUEDAS, L. A.; SALAZAR-BRAVO, J.; TINNIN, D. S.; ARMIÉN, B.; CÁCERES, L.; GARCIA, A.; DÍAZ, M. A.; GRACIA, F.; SUZAN, G.; PETERS, C. J.; YATTES, T. L.; MILLS, J. N. Community ecology of small mammal populations in Panamá following an outbreak of Hantavirus Pulmonary Sindrome. Journal of Vector Ecology, v. 29, n. 1, p. 1771191, 2004.

SAMPAIO, L. F. O aparecimento, a expansão e o fim da leishmaniose no Estado de São Paulo. Revista Brasileira de Medicina, v. 8, n. 10, p. 717-21, 1951.

SANTIAGO, M. E. B.; VASCONCELOS, R. O.; FATTORI, K. R.; MUNARI, D. P.; MICHELIN, A. F.; LIMA, V. M. F. An investigation of Leishmania spp in Didelphis spp from urban and periurban areas in Bauru (São Paulo, Brazil) Veterinary Parasitology, v. 150, p. 283-290, 2007.

SCHLOEGEL, L. M.; DASZAK, P.; NAVA A. Conservation medicine: tackling the root causes of emerging infectious diseases and seeking pratical solutions. Natureza \& Conservação, v. 3, n. 2, p. 135-146, 2005.

SHIMABUKURO, P. H. F. Chave de identificação ilustrada dos phlebotominae (díptera, psychodidae) do Estado de São Paulo, 2007. Tese (Doutorado em Ciências) -

Coordenadoria do Controle de Doenças, Secretaria de Estado da Saúde de São Paulo..

SILVA, A. M.; CAMARGO, N. J.; SANTOS, D. R.; MASSAFERA, R.; FERREIRA, A. C.; POSTAI, C.; CRISTÓVÃO, E. C.; KONOLSAISEN, J. F.; BISSETO Jr., A.; PERINAZO, R.; TEODORO, U.; GALATI, E. A. B. Diversidade, Distribuição e Abundância de Flebotomíneos (Díptera: Psychodidae) no Paraná. Neotropical Entomology, v. 37, n. 2, p. 209-225, 2008. 
SILVA, E. A.; ANDREOTTI, R.; DIAS, E. S.; BARROS, J. C.; BRAZUNA, J. C. M. Detection of Leishmania DNA in phlebotomines captured in Campo Grande, Mato Grosso do Sul, Brazil. Experimental Parasitology, v. 119, p. 343-348, 2008.

SILVA, E. S.; GONTIJO, C. M. F.; PACHECO, R. S.; FIUZA, V. O. P.; BRAZIL, R. P. Visceral leishmaniasis in the Metropolitan Region of Belo Horizonte, State of Minas Gerais. Memórias do Instituto Oswaldo Cruz, v. 96, n. 3, p. 285-291, 2001.

SOS MATA ATLÂNTICA \& INPE. Atlas dos remanescentes florestais da Mata Atlântica período 1995-2000 - Relatório Final. São Paulo: SOS Mata Atlântica e Instituto de Pesquisas Espaciais, 2002. 43 p.

STEVENS, S. M.; HUSBAND, T. P. The influence of edge in small mammals: evidence from Braziliam Atlantic forest fragments. Biological Conservation, v. 85, p. 1-8, 1998.

TEODORO, U.; SALVIA FILHO, V.; LIMA, E. M.; MISUTA, N. M.; VERGINASSI, T. G.; FERREIRA, M. E. C. Leishmaniose Tegumentar Americana: flebotomíneos de área de transmissão no norte do Paraná, Brasil. Revista de Saúde Pública, v. 25, n. 2, p. 129-133, 1991.

TEODORO, U.; SALVIA FILHO, V.; LIMA, E. M.; SPINOSA, R. P.; BARBOSA, O. C.; FERREIRA, M. E. C.; LONARDONI, M. V. C. Observações sobre o comportamento de flebotomíneos em ecótopos florestais e extraflorestais, em área endêmica de leishmaniose tegumentar americana, do norte do Estado do Paraná, sul do Brasil. Revista de Saúde Pública, v. 27, n. 4, p. 242-249, 1993 a.

TEODORO, U.; SALVIA FILHO, V.; LIMA, E. M.; SPINOSA, R. P.; BARBOSA, O. C.; FERREIRA, M. E. C.; SILVEIRA, T. G. V. Flebotomíneos em área de transmissão de leishmaniose tegumentar na região norte do Estado do Paraná - Brasil: variação sazonal e atividade noturna. Revista de Saúde Pública, v. 27, n. 3, p. 190-194, 1993 b.

TERBORGH, J. Maintenance of Diversity in Tropical Forest. Biotropica, v. 24, n. 2B, p. 243 $-292,1992$.

TOLEZANO, J. E. Epidemiological aspects of american cutaneous Leishmaniasis in the State of Sao Paulo. Memórias do Instituto Oswaldo Cruz, v. 89, n. 3, p. 427-434, 1994.

TOLEZANO, J. E.; TANIGUCHI, H. H.; ELIAS, C. R.; LAROSA, L. Epidemiologia da Leishmaniose Tegumentar Americana no Estado de São Paulo. III Influência da ação antrópica na sucessão vetorial da LTA. Revista do Instituto Adolfo Lutz, v. 60, n. 1, p. 47 $51,2001$. 
TOLEZANO, J. E.; ARAUJO, M. F. L.; BALANCO, J. M. F.; VALENTIM, A. M.; BARCA, M. L. Leishmania sp isolated from blood heart of Akodon sp (Rodentia Cricetidae) caught in Iguape City, São Paulo State, Brazil. Memórias do Instituto Oswaldo Cruz, suppl. 1, v. 83, p. 38, 1988.

TRAVI, B. L.; ADLER, G. H.; LOZANO, M.; CADENA, H.; MONTOYA-LERMA, J. Impact of habitat degradation on Phebotominae (Díptera: Psychodidae) of tropical dry forests in Northern Colombia. Journal of Medical Entomology, v. 39, n. 3, p. 451-456, 2002.

TURNER, I. M. Species loss in fragments of tropical rainforest: a review of the evidence. Journal of Applied Ecology, v. 33, n. 2, p. 200-209, 1996.

YOSHIDA, E. L. A.; SILVA, R. L.; CORTEZ Jr., L. S.; CORREA, F. M. A. Encontro de espécie do gênero Leishmania em Didelphis marsupialis aurita no Estado de São Paulo, Brasil. Revista do Instituto de Medicina Tropical de São Paulo, v. 21, n. 2, p. 110-113, 1979.

VALLADARES-PADUA, C.; PADUA, S. M.; CULLEN JR., L. Within and surrounding the Morro do Diabo State Park: biological value, conflicts, mitigation and sustainable development alternatives. Environmental Science \& Policy, v. 5, n. 1, p. 69 -78, 2002.

VELOSO, H. P.; RANGEL-FILHO, A. L.; LIMA, L. C. A. Classificação da vegetação brasileira, adaptada a um sistema universal. Rio de Janeiro: Fundação Instituto Brasileiro de Geografia e Estatística - IBGE, Rio de Janeiro, 1991. 123 p.

YAMAMOTO, A.; BERTOLINI, D.; MURAMOTO, J. Pontal verde: plano de recuperação ambiental nos assentamentos do Pontal do Paranapanema. Sao Paulo: ITESP, 1998. 65 p. 


\section{APÊNDICES}

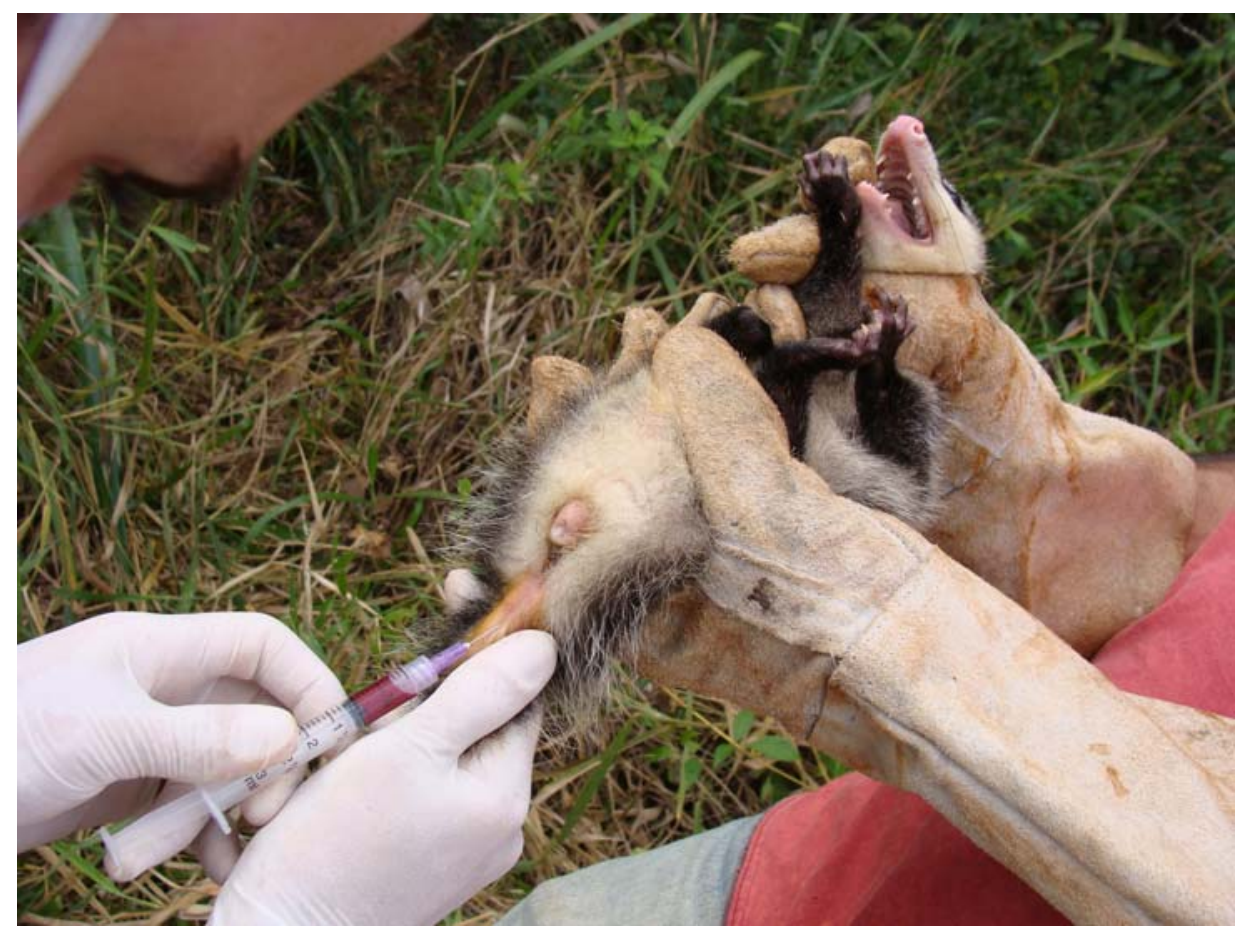

Figura 7 - Didelphis albiventris submetido à coleta de sangue

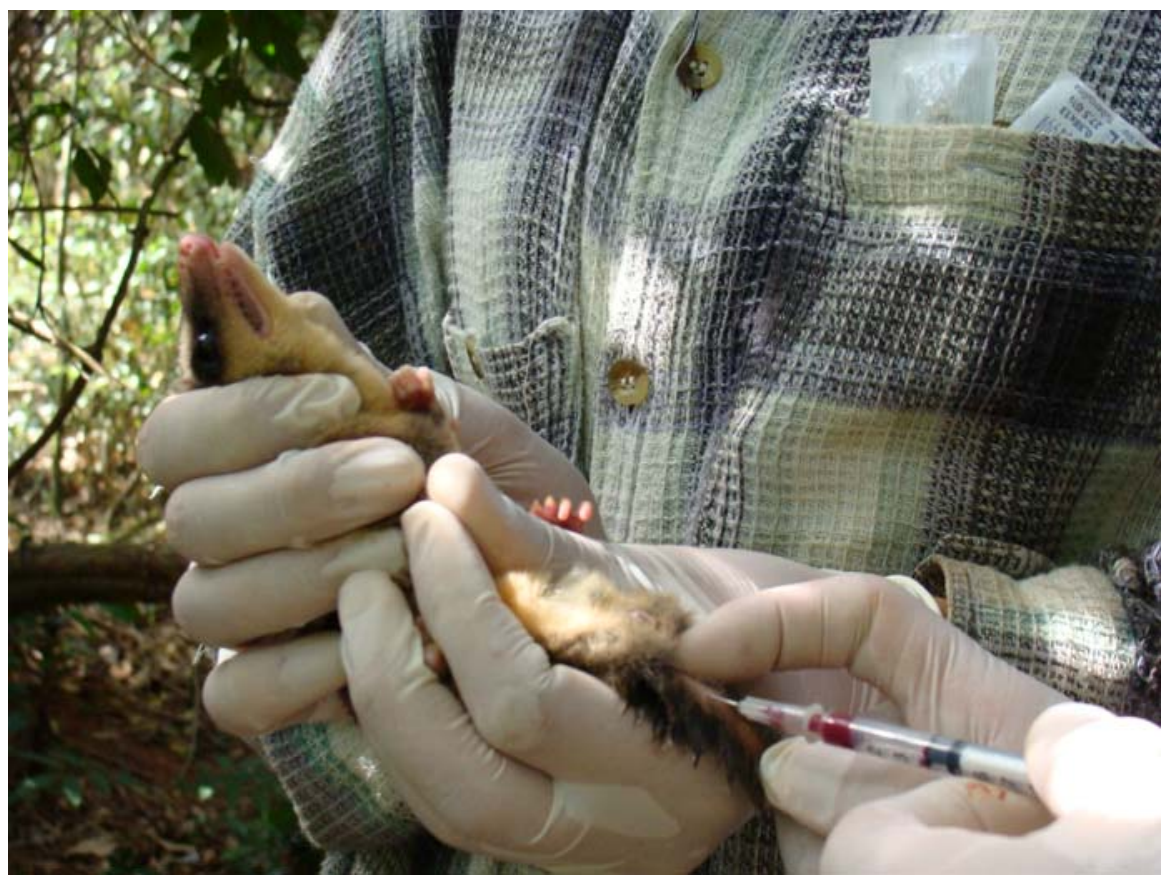

Figura 8 - Micoureus paraguayanus submetido à coleta de sangue 


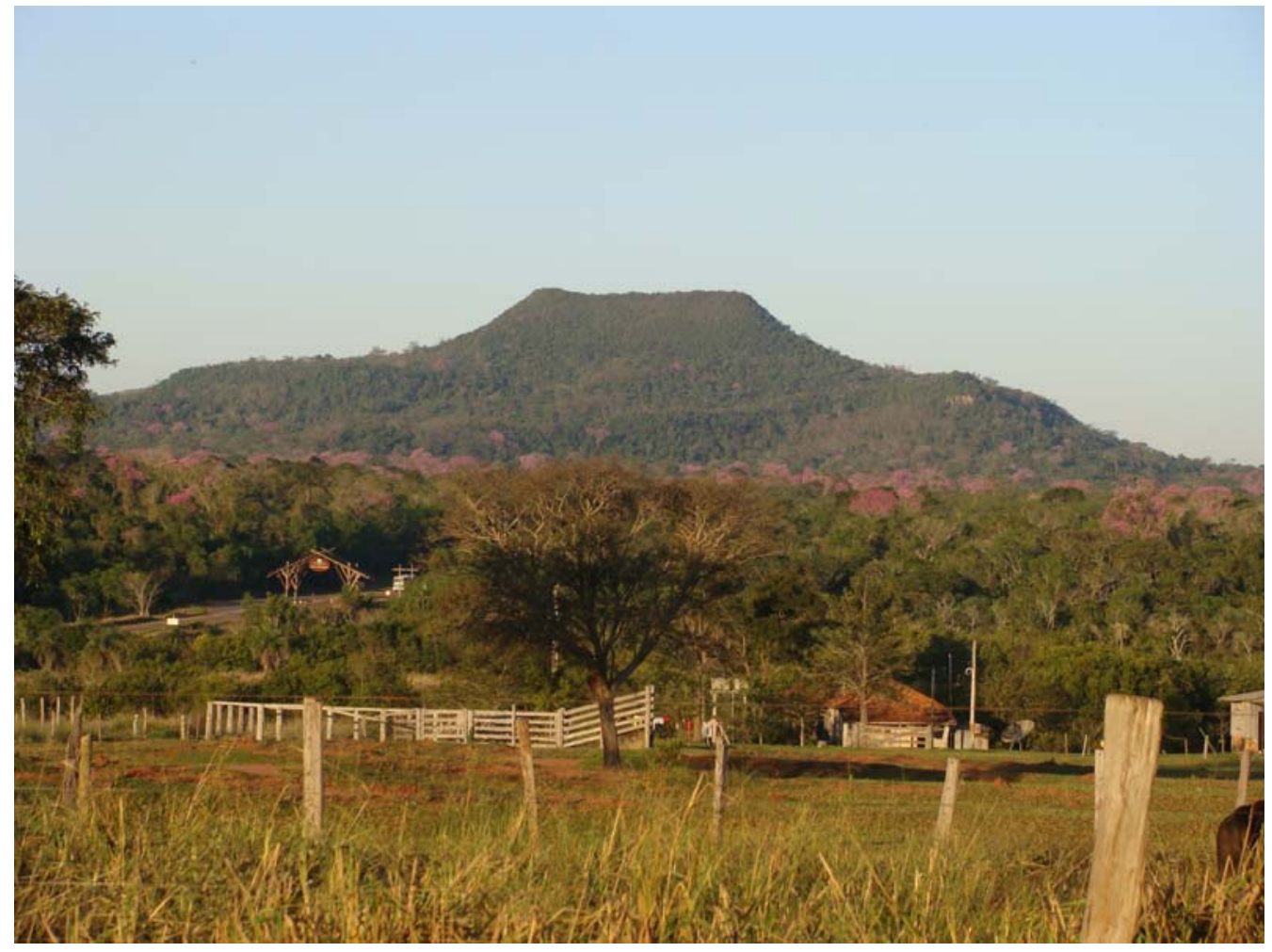

Figura 8 - Borda do Parque Estadual Morro do Diabo

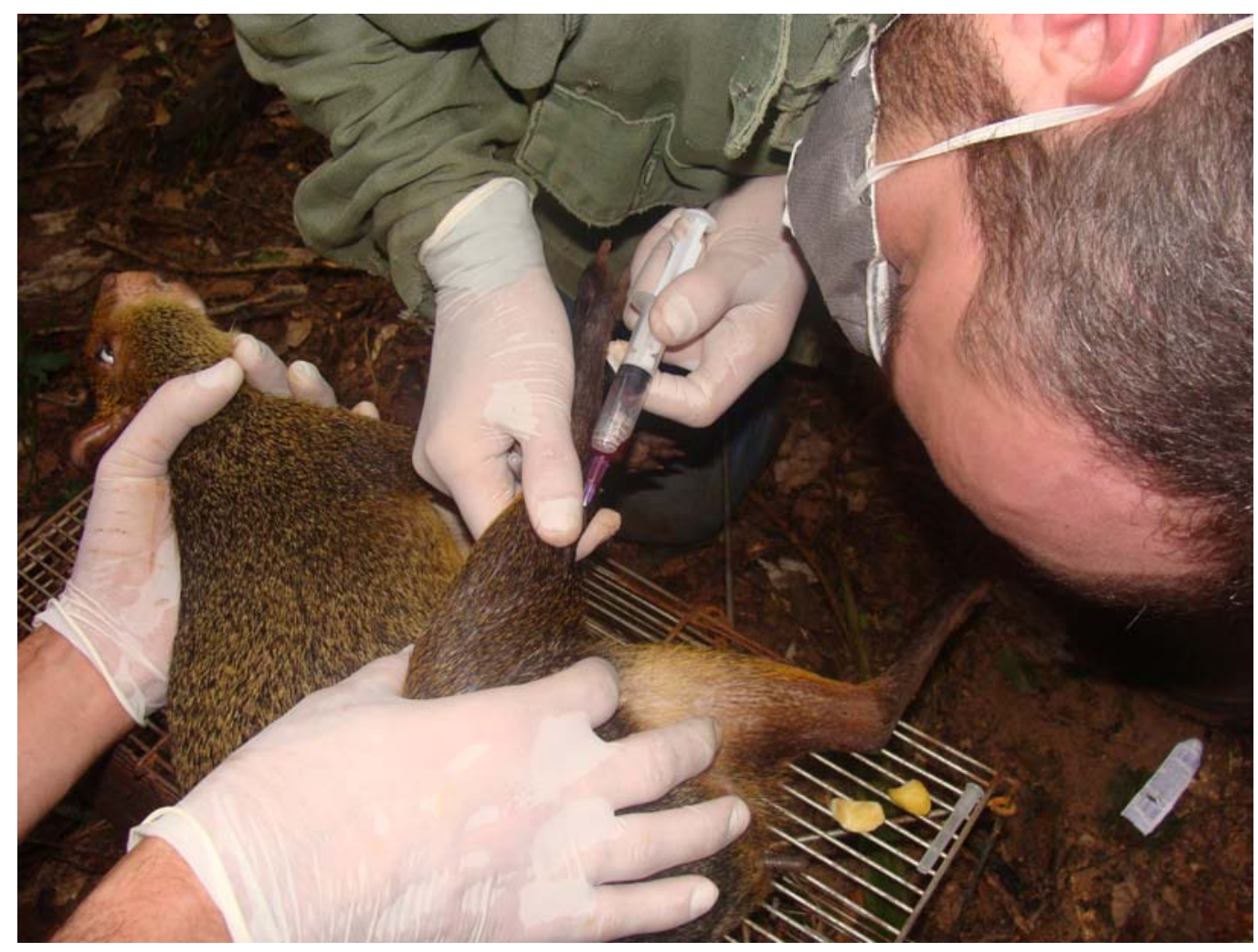

Figura 9 - Dasyprocata azarae submetido à coleta de sague 


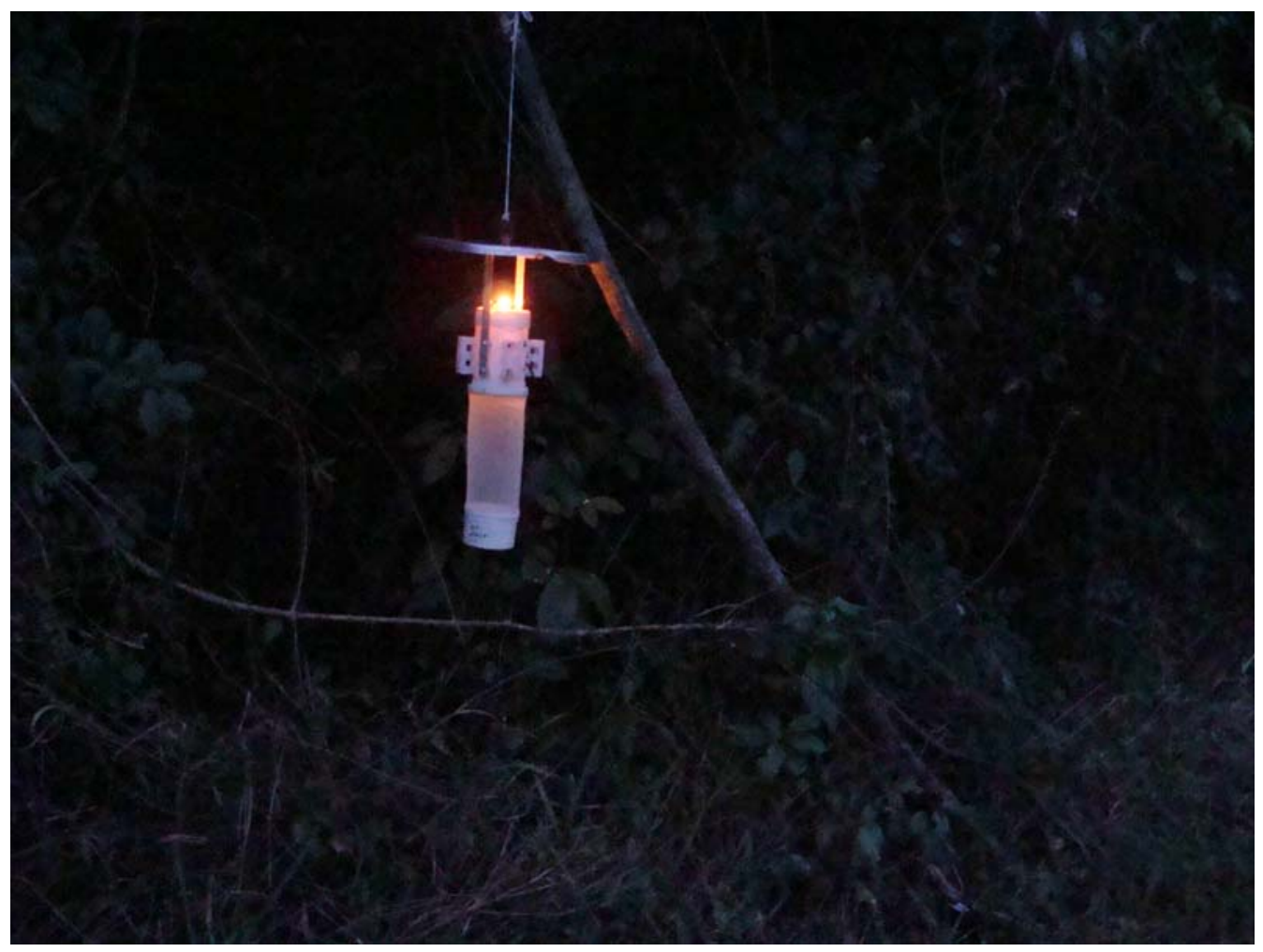

Figura 10 - Armadilha luminosa instalada na borda da mata

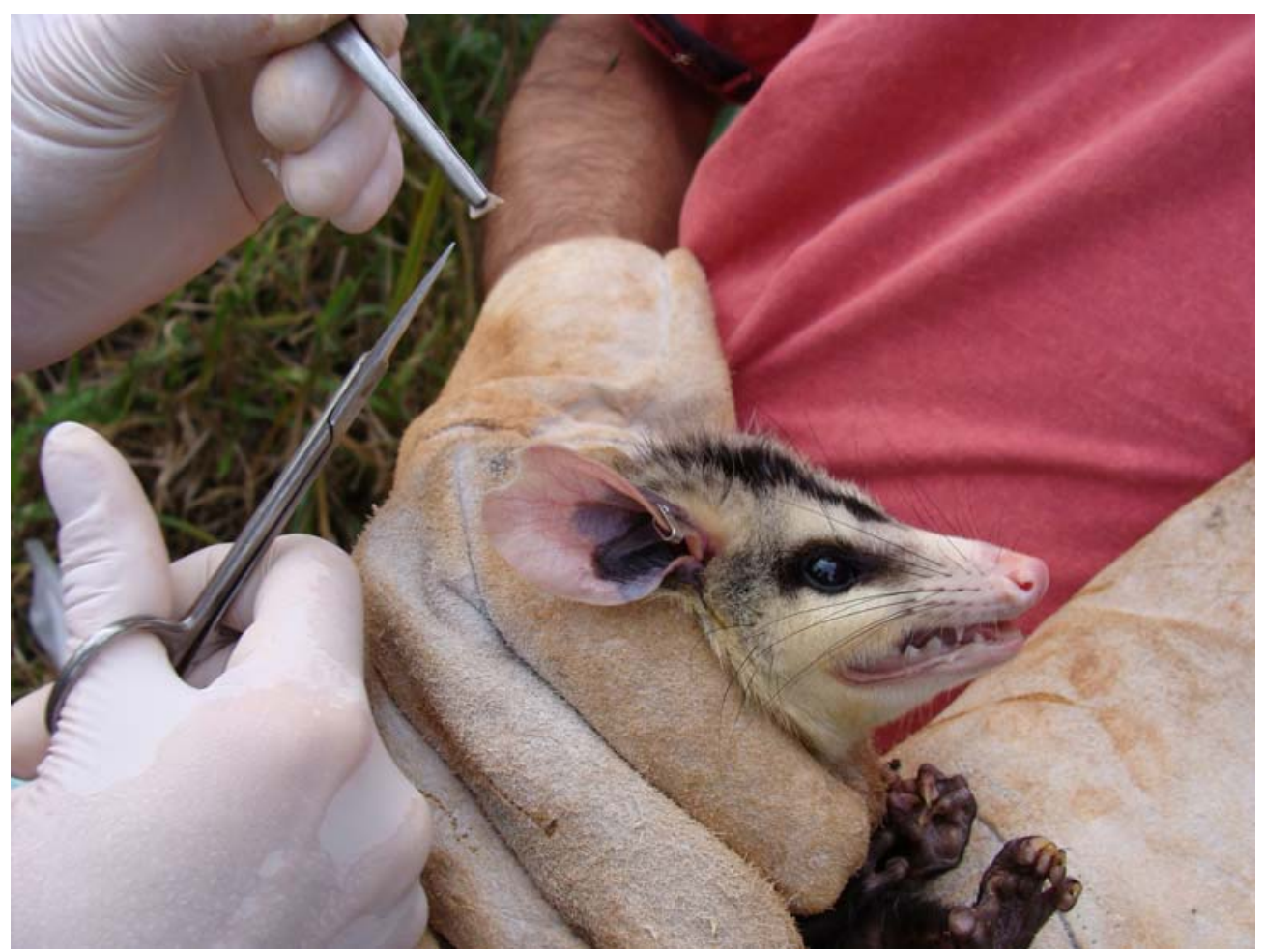

Figura 11 - Coleta de pele em Didelphis albiventris 